\title{
The Effect of Position in the Field in the Development of Public Policies: Bourdieusian analysis of the Municipal Tourism Council of Juiz de Fora [2011-2020]
}

\author{
Thiago Duarte Pimentel, Marcela Costa Bifano de Oliveira, Fabíola Cristina Costa de Carvalho*
} ABSTRACT

Keywords:

Bourdieu,

Tourism,

Tourist Councils
This work makes efforts for a theoretical-empirical analysis of public policies of tourism from the sociological theory of the social fields of Pierre Bourdieu. We start from the assumption that agents with a greater volume of capital would be able to interfere, more incisively, in the tourist field, particularly in their public policies, influencing more forcefully what can/should be and ends up being done, in a given context. Empirically, we took as study object the Municipal Council of Tourism of Juiz de Fora (COMTUR), heuristically as an approximation of the tourist field in general, and specifically the process of elaboration of public policies derived from it, in particular in terms of its results (decisions, actions and projects carried out), as a reasonably objective indicator of the operation of this field. A multi-methods approach was used, using different procedures (a) systematic and unsystematic observation of meetings, (b) description and recording of data in a diary note, (c) semi-structured interviews with key actors, (d) analysis of secondary data (minutes of COMTUR meetings from 2011 to 2020, as well as other data and historical records). The study is based on the composition of a cumulative database of observations, which has been constituted over the last decade, being specifically composed in the most part, regarding the study of COMTUR, by two studies, one conducted between 2015 and 2016, which recovered data from 2011 to 2015, and the other, conducted between 2019 and 2020, that compiled data from 2016 to 2020. We seek to identify the relationships between the different agents in the interactive dynamics of this social space, in terms of ideas, discourses and actions, as well as the positions of the agents, particularly the dominant ones, which stand out in relation to the others. We particularly highlight the relationships between proposed-proposals, approved-executed proposals, as well as between both and the volume of capital of the agents, especially the dominant ones, and finally the specific circumstances of each action (proposed and approved). The evidence points towards a direct relationship between the said volume of capital, the degree of participation in the meetings and the tendency to approve and eventual implementation of the proposals made by the agents with the highest volume of capital, who were at the center of the debate. It is concluded that the supposed democratic and "universal" openness in terms of the possibility of action is part of an ilusio of the field, which does not translate necessary, neither directly, in the real manifestation and participation in the field (COMTUR). It is said that the agents with the highest volume of capital tend to be those who, in a way, participate more in the actions and achievements of this sphere and, in this sense, are more likely to guide the local tourist context, as opposed to the actions of other agents in the field, who act as adjuvants. Therefore, any significant change in the field needs to include, in whole, or in part, those

\section{dominant agents.}

Article History:

Submitted: 07.05.2021

Accepted: 15.12.2021

\section{Doi: https://doi.org/10.31822/jomat.2021-SP-1-89}

\section{Introduction}

In recent years, management councils have become synonymous (in common sense) with democratic and participatory management (Paes de Paula, 2008) ${ }^{1}$. To this logic underlies the thesis that in appropriate spaces, free of coercion (imposed or self-imposed), social actors could express themselves in a more authentic and reliable way and assert their local interests and ideas (Tenório, 2008). Through the management councils, the various actors have the possibility to manifest and participate in the formulation, monitoring and control of the public policies (Gohn,

\begin{aligned} \hline *Corresponding Author & \\ \hline Thiago Duarte Pimentel: & $\begin{array}{l}\text { Assoc. Prof., Universidade Federal de Juiz de Fora (Brasil), Juiz de Fora, Brasil, Email: thiago.pimentel@ ich.ufjf.br, } \\ \text { Orcid Id: 0000-0003-1889-069X (iD }\end{array} \\$\hline Marcela Costa Bifano de & PhD. Student, Centro Universitario de la Costa - Universidad de Guadalajara (Mexico), Juiz de Fora, Brasil, Email: \\ Oliveira: & marbifano@gmail.com, Orcid Id: 0000-0002-8102-5247 (D) \\ \hline Fabiola Cristina Costa de & Independent Researcher, Benemerita Autónoma Universidad de Puebla, Puerto Vallarta, México, Email: \\ Carvalho: & fabiola.cvlho@ @mail.com, Orcid Id: 0000-0001-5719-9020 (D) \end{aligned}


2011; Instituto de Pesquisa Econômica Aplicada IPEA, 2012; Mata, 2016), supposedly exercising greater social control over the State (Gurgel \& Justen, 2013; Gomes, 2015; Lima \& Brito, 2021). Its use has spread more and more throughout the country and has been institutionalized in several instances and at the three levels of the State, and even in private organizations ${ }^{2}$.

Despite their possible contributions, there have been several situations in which these mechanisms have presented questionable results (Abramovay, 2001). The symbolic use of councils, only as a formal mechanism for enabling the management entity (municipal, state or federal) to the legislation, has been constantly verified (Gohn, 2011). Many times, the deliberation and decisionmaking of the topics discussed in this space is not the result of a process of discussion among the participating members. This happens because instead of participation acquiring an effectively deliberative character, it usually acquires an advisory role, legitimizing the decisions established by the government and local elites, leading to the questioning of what many relate to these decision-making bodies, of being a democratic innovation (Kronemberger, 2016).

Moreover, there are rare occasions when there is a fragile assumption that the actors would participate more effectively as a basis for this device (Kliksberg, 1998). On the contrary, complaints of ignorance, lack of interest and questioning about the relevance and applicability of these structures, are combined with their visualization as time-consuming, nonspecific, inconclusive and unpragmatic (Nobrega \& Figueiredo, 2014). All this has led to the questioning of the management councils as instruments of empowerment and social control (Mata, 2016; Mata; Pimentel \& Emmendoerfer, 2018).

In order to analyse more closely this issue, we use Pierre Bourdieu's sociological theory of social fields, investigating the volume of capital of agents, which enable them to play certain roles within a social field (whether in a company or in a council) and take as empirical object of analysis the Municipal Tourism Council of Juiz de Fora (COMTUR, in Portuguese acronyms ${ }^{3}$ ), to analyse how certain agents influence the dynamics of the said board, which materialize in projects or actions that must be executed. We relate this event to the conditions and characteristics that determine the ability of those agents to perform such actions. We start from the assumption that agents with a higher volume of capital would have greater capacity to interfere in the tourism field, from the establishment of a power relationship over the others, thus being able to interfere more forcefully in what should or should not be done.

The relevance of this type of study lies precisely in the fact that, as traditional perspectives, with structural functionalist cutting, have been widely used for studies in public policies; few studies operates with alternative theoretical lenses (Marques \& Machado, 2014; Mata; Pimentel \& Emmendoerfer, 2018) 4 . Such studies, by problematizing the issue of power relations, an aspect that is underexplored and sometimes omitted from other perspectives, can contribute to shed light on asymmetric social relations in contexts of participation and democratic public spaces, where a certain asymmetry of power between participants and horizontal participation is assumed; which in general is not verified in practice (Pimentel et al., 2020).

Elements of bourdieusian analysis ${ }^{5}$ of social fields were used as empirical method, together with the unsystematic observation of meetings, interviews and in a privileged way the minutes of the COMTUR meetings from 2011 to 2020. The relations between proposers and proposals, proposals approved and implemented, the relations between proposers and approved proposals and then between those and the proposals implemented, as well as the circumstances of each action and the provisions of the agents were identified. The evidence points to a direct

\footnotetext{
2 See the boards of directors of large, national and international, companies, marketed on the stock exchange. In fact, the management boards in private companies emerge as one of the mechanisms for solving the "agency conflict", which gradually-in the context of the literature on governance that will move from the private to the public sector in the early 1970s and onwards-will be absorbed into the public area, based on the thesis of the inclusion of several controllers (a supposed social panoptism). 3 All of the acronyms mentioned in this paper refer to Portuguese writing.

4 Conducting a bibliographic meta-study on the 831 scientific works published in the Annals of the "Encontro Anual da Associação Brasileira de Ciência Politica/ABCP", in the period from 2000 to 2012, these authors found that, contrary to what happens in the great area of social sciences, where Pierre Bourdieu is the author with the highest number of citations (13.4\%) of the total, specifically in the area of political science, in Brazil, this scenario is inverted, and Bourdieu does not even appear in the list of the 12 most cited, those with a frequency greater than or equal to $8.4 \%$ (the equivalent of 28 citations in the entire period analysed).

5 This study does not strictly follow a methodological bourdieusian perspective. This for two reasons: the first is that in addition to the issues of theoretical (re) construction (of the research object, i.e., field) and historical construction, several quantitative, qualitative, bibliographic and historical procedures were used by the author for analysis of a field, with no specific way to do so; and, on the other hand, by the fact that the original research, and the theoretical-epistemological orientation that guides it, as well as the research group led by the first author, are influenced by critical realism, which sees this -even though Bourdieu is not part of it-in the works of this author an emblematic example of anticipation and convergence, in various theses, in particular methodological, of a realistic critical work "outside" the tradition of critical realism (Vandenberghe \& Veran, 2016).
} 
relationship between the volume of capital of the agents, their degree of participation (frequency and deliberation), the occupation of key positions (e.g., composition of the Executive Board) and the tendency to approve and execute the proposals.

In addition to this introduction, we present below a brief description of Pierre Bourdieu's sociological theory, with emphasis on his central concepts of field, capital and habitus. In the third section, the methodology of the study is exposed with emphasis on elements of the analysis of social fields. The fourth section presents the results of the research, in which the historical context of COMTUR is observed, the participation of the agents, its dispositions, its composition and its correlation with the volume of capital of the agents. At the end, we present inferences about the volume of capital to its tendency to convert into capacity of action and to the direction, either by action or omission, of the local tourist context.

\section{The Field as a Theoretical-Analytical Framework}

\section{Pierre Bourdieu's Sociological Theory}

Pierre Bourdieu's work develops a critical sociology that, while part of the existence of objective structures, maintains that these structures are products of social construction (Thiry-Cherques, 2006). The central axis of Bourdieu's genetic structuralism is the analysis of objective structures, which are not fixed, but rather the result of the history of the positions and dispositions that reproduce it, that is, it is the product of the relationships that develop in time and space (Pimentel, 2012; 2014).

In this sense, Bourdieu elaborates a theory that incorporates the concepts of field, capital and habitus to identify the relationships between individual or collective agents, who through strategies struggle to reach their interests and dominate the field. The field can be defined as a default or a setting of objective relationships between positions. These positions impose determinations on their occupants, agents or institutions, for the current or potential situation in which they are on the scale of the different species of power (or capital), whose disposition commands access to the benefits that are at stake in the field (Bourdieu, 1993).

Forms of capital mean forms of power. For Bourdieu (2001) capital is accumulated work in the form of internalized or incorporated matter, and time is required for its acquisition. The different forms of capital that allow specifying the notion of position are defined as follows: (1) economic capital - money, goods, material wealth; (2) social capital social access, networking; (3) cultural capital knowledge, skills, information; (4) symbolic capital - prestige, honour, is a synthesis of other capitals (Pimentel, 2014). Thus, objective relations are the relations between the positions occupied in the distributions of resources, economic capital, cultural capital, social capital, recognized as legitimate (Bourdieu, 1990; 2004). In this sense, the position of each agent is determined by the volume and quality of capital that each one has (Thiry-Cherques, 2006).

According to Bourdieu (1993) a capital only has meaning in a field if it confers a power over the field. Thus, what defines the field is the state of power relations between players, which depends on their position, consequent to the distribution of specific capital. But it should be noted that the value relationships between capitals are not static, players can work on increasing or preserving their capital, or they can also work to transform the immanent rules of the game. Thus, the field as a structure of objective relations between positions of force, sustains and guides the strategies by which the occupants of these positions fight, individually or collectively, to protect or improve their position and enforce the principle of settlement more favourable to their own interests (Bourdieu, 1993).

These struggles aim at the monopoly of legitimate violence (authority) that is characteristic of the given field, that is, the conservation of the structure of the distribution of specific capital. Those who monopolize specific capital, which are those with power and authority, tend to conservation strategy, while those with less capital tend to transform strategies (Bourdieu, 1983). Symbolic power is then defined as the ability to preserve or transform social reality, from cognitive instruments of construction of the reality (Wacquant, 2002).

There is therefore, in this social space, a conflict between those who dominate and those who are dominated. Thus, the institutions of a given field tend to "impose" the dominant culture, so that the habitus is reproduced (Thiry-Cherques, 2006), and that the structure of dominant and dominated is maintained, ensuring that capital (cultural, economic and social) is not redistributed, operating in favour of the conservation of the distribution of capital among the same agents, keeping them in a privileged position. In specific terms, the field involves a doxa (common sense) and nomos (general laws that govern it). 
For Bourdieu, habitus is a system of dispositions (way of thinking, of doing, of feeling) that lead us to act in a certain way, in certain circumstances. The provisions (habitus) are flexible, are acquired by the internalization of social structures, are carriers of individual and collective history, are internalized in a way that we ignore their existence (Thiry-Cherques, 2006). Habitus is a particular way of relating to the world, it is structured and structuring: it is a product of the structure and producer of practices, a reproducer of structures (Bourdieu, 1993), so it represents not only a conditioning, but an action. As Vandenberghe (2010) comments, habitus is the product of social structures, but we must go beyond the pure deterministic trap, since habitus as a generating principle of actions, evaluations and perceptions, also structures the social world.

In this way, the strategies of the agents for taking position depend on the position they occupy in the field, and through their provisions (habitus) will be oriented to the conservation or subversion of this distribution of capital (perpetuating or changing the rules of the game). The strategies, through the objectives of the fight, also depend on the space of availability inherited from previous fights, which will define the space of taking position. From the position and the provisions (which are due to their social origin) is that the agent orients himself towards such or what possibilities, all in an unconscious way (Bourdieu, 1996).

Proximity in the social space predisposes an approximation, that is, people located in the same place of space (classes) tend to be closer by their properties or their dispositions (which determine the tastes, affinities, sympathies, desires, so the probability of them sympathizing is greater) (Bourdieu, 1996).

$[\ldots]$ the position occupied in the social space, that is, in the distribution structure of different types of capital, which are also weapons, commands the representations of this space and the positions taken in the struggles to keep or transform it (Bourdieu, 1996: 97).

This is how concepts such as habitus, field and capital cannot be defined in isolation, but only within the theoretical system of which they take part (Bourdieu, 1993). The field is the place of relations of strength and struggles in the sense of transforming it, thus it can be characterized by a place of permanent change (Bourdieu, 1993). Thus, the social field can be seen, in a simplified way, as a system of relations between the social positions of the agents, which is the objective part, determined by the amount of capital of each agent in the field, by the provisions that is the subjective part of the field, composed by the habitus, which will determine what the agent is willing to do or not, and positions taking that refer to a position, in which positions and habitus are expressed in the sense of ruptures or continuities of the structures of the field.

To examine a social field, three interconnected stages must be followed. First, one must analyse the position of the field in relation to the field of power. Secondly, the objective structure of the relations between the positions occupied by the agents or the institutions that are in competition in this field must be defined. Thirdly, the habitus of agents, the position taking they have acquired through the internalization of a certain type of social and economic conditions they find (Bourdieu, 1993) should be analysed. Bourdieu (1993) adds that the field of positions is methodologically inseparable from the field of position taking (structured system of practices and expressions of agents) and in equilibrium situation the space of positions tends to command the space of positions.

\section{Methodology}

This study is based on bourdieusian theory, which seeks to study the "social fields". It is specified through different thematic areas that regulate objects of interest and dispute on the part of agents

Figure 1. Theoretical synthesis.

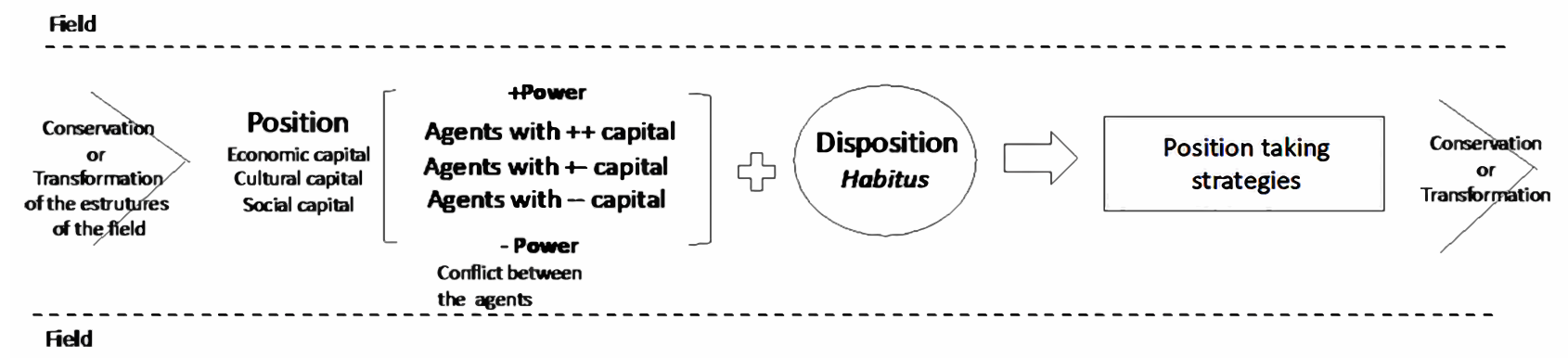

Source: Authors elaboration. 
in reality. According to Wacquant (2002) this sociological theory resulted in an original theoretical field, unveiling the dialectic of social and mental structures in the domination process. Thus, Bourdieu's (2004) work can be understood as a structuralist constructivist, because he understands that there are objective structures in the social world (language, myth, etc.) that guide or coerce the practices and representations of agents, regardless of their conscience or will, but recognizes how these agents interact and socially rebuild those structures. Therefore, the logic of scientific research should be to seek to identify such structures and unveil the mechanisms that regulate them, both their form of reproduction and modification, over time.

Empirically we take as object of study the interactive dynamics among the agents of the tourist field (COMTUR of Juiz de Fora-MG) in the period from 2011 to 2020. The Municipal Tourism Council is heuristically an approximation of the tourist field in general, and the process of elaboration of public policies derived from it, in particular, in terms of its results (decisions, actions and projects carried out), can be perceived as reasonably objective indicator of the functioning of this field.

Here three definitions are important: the first refers to the consideration of public policy as an object of dispute (Bifano-Oliveira \& Pimentel, 2016). We assume this proposition as a premise, since a policy, like any action of a State, acts universally on all the actors involved and subordinated to it, in addition to what, in the case observed, is the object of dispute since it directs the common understanding (doxa), rules (nomos) and practices (habitus) and imposes a "di-vision" of the world (Bourdieu, 1989: 113), in which the dominant (established) vision will determine the legitimate forms and means by which it can compete for scarce resources, thus regulating the rules of the game in the interaction between the agents that compose it.

The struggles regarding ethnic or regional identity, that is, regarding properties (stigmas or emblems) linked to origin through the place of origin and the lasted signs that are correlative to them, such as the accent, are a particular case of the struggles of the classifications, struggles for the monopoly of making it known and believed, to make known and to make recognize, to impose the legitimate definition of the divisions of the social world and, in this way, to make and undo the groups. In fact, what is at stake in them is the power to impose a vision of the social world through the principles of di-vision that, when imposed on the group as a whole, they realize meaning and consensus about the meaning and, in particular, on the identity and unity of the group, which make the reality of the unity and identity of the group (Bourdieu, 1989: 113 - bold added).

The second reading key to the issue lies in the possibility of heuristic and methodological approximation between the social space of the tourist field and the Municipal Tourism Council to the extent that it gathers most of the agents of this field in the destination studied and still a considerable part of the most important visible agents. On the other hand, it is recognized that the social space of a social field (in this case, tourism) overflows and exceeds the limits of the standardized institutional space of a council (it may even contain the COMTUR), and that even relevant agents may not be part of it, being "invisible" in the methodological option of fixing to the agents present in the social space of COMTUR. Nevertheless, this methodological option is justified since COMTUR brings together, in an extensive (mostly numerically), and intensive (considerable part of the main), the actors of the field.

A third important element concerns the common imaginary (doxa) established, through an homogenizing discourse with institutional legitimacy, and the framing (in this case even more formal) of agents and their actions, generated in the social space, whose results depend not only on the interactive process of the forces of the field "itself", but on the interface and transfer of these "results" to other fields, for example, that of the State, i.e. public management (bureaucratic administration), in the case analysed, on a municipal scale, which in turn is a tributary of the partial merger of two other independent social fields: political and economic (Bourdieu, 2004).

In addition to these considerations, a multi-system approach was used, using different procedures: (a) systematic and unsystematic observation of meetings, (b) description and recording of data in a field diary note, (c) semi-structured interviews with key actors, (d) analysis of documentary data (minutes of COMTUR meetings from 2011 to 2020, Bylaws and Municipal Tourism Plan), as well as other secondary data and historical records.

The study is based on a cumulative database of observations about the study object, which has been constituted over the last decade, and it is particularly important to highlight for this study, two researches, one conducted between 2015 and 2016, which retrieved data from 2011 to 2015, and another, conducted between 2018 and 2019, which compiled data from 2016 to 2018. This material was complemented by the analysis of the data of 
Table 1. Research design

Phase 1: Collection of primary and secondary data

\begin{tabular}{|c|c|c|c|c|}
\hline \multicolumn{2}{|c|}{$\begin{array}{l}\text { STEP 1: Election of a public tourism } \\
\text { policy as an object of dispute in the } \\
\text { field. } \\
2.1 \text { Election of a public tourism } \\
\text { policy for the empirical analysis of the } \\
\text { agents involved with it. }\end{array}$} & \multicolumn{2}{|c|}{$\begin{array}{l}\text { STEP 2: Mapping of the agents present in the field in the } \\
\text { municipality and their interaction with the elected policy (object } \\
\text { of dispute). } \\
3.1 \text { Research on COMTUR, its operation, and its members } \\
\text { representing the agents that make up the tourist field. } \\
3.2 \text { Analysis of minutes of COMTUR meetings in the period } 2011 \\
\text { to } 2020 \text {, and the Bylaws }\end{array}$} & $\begin{array}{l}\text { STEP 3: Primary data } \\
\text { collection. } \\
\text { 4.1 Application of semi-structured } \\
\text { interview with key agents and } \\
\text { direct observation (notes in the } \\
\text { diary). }\end{array}$ \\
\hline \multicolumn{5}{|c|}{ field } \\
\hline Concepts & \multicolumn{2}{|l|}{ Categories } & \multicolumn{2}{|l|}{ Criteria } \\
\hline $\begin{array}{l}\text { STEP 4: Position } \\
\text { - quantitative } \\
\text { study of the } \\
\text { volume of capital } \\
\text { of each agent }\end{array}$ & \multicolumn{2}{|l|}{$\begin{array}{l}\text {-Economic capital } \\
\text {-Cultural capital } \\
\text {-Social capital } \\
\text {-Trajectory }\end{array}$} & \multicolumn{2}{|c|}{$\begin{array}{l}\text { It is the objective side of the field, the place of social hierarchy that each agent occupies in the } \\
\text { field. We can verify it from the economic, social and cultural capital of each agent. Social } \\
\text { capital is verified from the resource relating to the relationships that organizations establish } \\
\text { with other organizations. Cultural capital is verified from the resource relating to the education } \\
\text { level of the representative of the organization. Economic capital is verified from the available } \\
\text { financial resources, that is, the annual assumption of each organization. }\end{array}$} \\
\hline STEP 5: Layout & \multicolumn{2}{|c|}{$\begin{array}{l}\text {-Habitus, position taking of } \\
\text { agents to act according to } \\
\text { what has been internalized. }\end{array}$} & \multicolumn{2}{|c|}{$\begin{array}{l}\text { The subjective side of the field is determined by the habitus and the position taking of agents } \\
\text { to act according to what has been internalized. It is verified from the mission, vision and } \\
\text { objectives of organizations, it is also verified from the context of policies in the country and in } \\
\text { the municipality. }\end{array}$} \\
\hline
\end{tabular}

the minutes, documents and actions of that social space and its agents of the years 2019 and 2020, in order to have a vision and a balance of what was produced in a decade.

In the specific case of this research, what is intended to be studied is the (social) field of tourism. However, the sociological analysis of the tourist field is conditioned by multicausal elements, because tourism is formed by a complex structure of social actions and relations. Thus, the importance of different research techniques is defended, which complement each other to identify and analyse the mechanisms that structure the action of the agents of the tourist field. Thus, the design of this research is guided by the mixed method, done in 5 stages, divided into two phases, described in Table 1, applied to each period.

Following the path of a bourdieusian analysis, this research used multi-methods and different procedures for compiling the largest number of data and information, of different types, and reconstitution of social reality as broadly as possible, with a view to having a reading of the social field on screen and the interactions between agents. Four categories were central to this process: a) the historical constitution of field; b) the agents that compose it; (c) habitus, the provisions of the agents; and (d) the distribution of capital, the position of the agents and their ability to take action in the field.

Initially, secondary data were recovered from historical, documentary and statistical sources related to the object of study and its components, besides, of course, bibliographic materials related to the research theme that provided us with a selective, non-exhaustive theoretical review and focused on studies on Bourdieu. Within this corpus stand out the set of normative materials (minutes, laws, resolutions, regulations, etc.) of the municipal government, since they institute and regulate the social space of COMTUR, as well as statistics and historical data that were compiled for the historical reconstruction of the context of the locus and object of study. In the following stage, a mapping of the member agents of COMTUR individual, of organizations, entities and formal institutions- was made considering them representative of the tourist field of the municipality of Juiz de Fora.

The study took place in a cross-sectional way, in 2 moments: (1) between 2011 to 2015, 63 minutes were analyzed, available on the site of the

Table 2. Ordinary and extraordinary meetings from 2011 to $2020 *$.

\begin{tabular}{|c|c|c|c|c|c|c|c|c|c|c|c|c|c|c|c|}
\hline Minutes & $\mathbf{2 0 1 1}$ & $\mathbf{2 0 1 2}$ & $\mathbf{2 0 1 3}$ & $\mathbf{2 0 1 4}$ & $\mathbf{2 0 1 5}$ & $\mathbf{2 0 1 6}$ & $\mathbf{2 0 1 7}$ & $\mathbf{2 0 1 8}$ & $\mathbf{2 0 1 9}$ & $\mathbf{2 0 2 0}$ & $\mathbf{T o t a l}$ \\
\hline Ordinary & 12 & 12 & 11 & 13 & 12 & 10 & 3 & 6 & 8 & 6 & $\mathbf{9 3}$ \\
\hline Extraordinary & 2 & 1 & 0 & 0 & 0 & 5 & 24 & 10 & 0 & 0 & $\mathbf{4 2}$ \\
\hline Total & 14 & 13 & 11 & 13 & 12 & 15 & 27 & 16 & 8 & 6 & $\mathbf{1 3 5}$ \\
\hline
\end{tabular}

Note: Here were not counted the three ordinary meetings of the Municipal Tourism Fund (MTF), which dealt only with the report of the expenses of the MSD, referring to the meetings of October 30, 2013; April 30, 2014 and December 1, 2014.

* More detailed information see Appendix, table 6.

Source: own elaboration from the analysis of the minutes. 
Municipality of Juiz de Fora, in the space dedicated to $\mathrm{COMTUR}^{6}$. The analysis consisted of quantifying the participation related to attendance in meetings in order to verify which agents were more present, in addition to analyzing the position of the agents according to their volume of capital (economic, social and cultural). Analytically in a heuristic way, a s in an ideal type, we identified the position based on representative (but not exhaustive) criteria ${ }^{7}$ of each type of capital listed by Bourdieu: economic capital (annual budget of each individual or collective agent); cultural capital (education level of each representative of organizations); social capital (number of links/relationships with other organizations). (2) For the period from 2016 to 2018 , we based on the studies by Oliveira et al. (2020a; 2020b), in which minutes were analyzed from the 2 nd half of 2016 to December 2018, to which 14 minutes were added for the years 2019 and 2020. In all, in the period from 2011 to $2020^{8}, 135$ minutes were analyzed, in addition to other documents such as the Municipal Tourism Plan.

Regarding the primary data, semi-structured interviews, observation and notes were collected in a diary. At the first moment (2011-2015), the interviews were conducted with 21 members of COMTUR, 6 from the public sector (PS) and 15 from civil society (CS); and in the second moment (2016-2020), 7 members, being 3 associated with the PS and 4 linked to the CS (Oliveira et al., 2020a). All members were interviewed (president, vice president, secretaries and tax advisers) on both occasions.

Based on the empirical object of dispute (Municipal Tourism Policy) all the mentioned stages were carried out, and it was moved to phase 2 (data analysis), which took place in two more stages according to the set of categories analyzed. Thus, the position and disposition of the agents in relation to tourism policy was verified. These categories allow us to visualize that the action of the agents is determined by their position, that is, by the power they have in the field and their ability to influence decisions according to their interest, and by their willingness to do something in this field.

\section{Analysis}

Following the Bourdieusian analysis, we tried to recover different types of data and information with a view to having a broader reading of the social field and the interactions between the actors. Four categories were central to this process: a) the historical constitution of field; b) the agents that compose it; (c) habitus, the provisions of agents; and (d) the distribution of capital, the position of the agents and their ability to take action in the field.

With the exception of the historical constitution of the field, the other categories were analyzed in the period from 2011 to 2020: divided into 2 distinct periods, between 2011 and 2015, and between 2016 and 2020, because it understands that there are unique characteristics in each period, either in terms of the composition of the set of agents, or whether in terms of the guidelines, discourses and interactive dynamics installed in it, or even in relation to the pursued and achieved results.

\section{Historical constitution of the tourist field}

The historical process of constitution of tourism policies in Juiz de Fora is relatively recent, however marked by advances and setbacks, permeated by political discontinuities and absence of qualified technical staff and its own institutional body in the local public administration, which already denotes the little weight related to the importance attributed to the theme.

The policies of the sector were born, constituted and prevailed in the interval of the last

\footnotetext{
6 They can be found on the official website of the municipality, dedicated to COMTUR. Available in: https://www.pif.mg.gov.br/conselhos/turismolatas_de_reunioes.php. Accessed on April 29, 2016.

7 From the collection of primary data (interviews), we created a scale from 1 to 8 for each capital. For economic capital, the scale was based on the annual budget of each entity interviewed, its calculation was made from the subtraction between the largest budget and the smallest budget divided by 8 (scale) to calculate the amplitude of the scales, with this it was possible to determine on which scale each entity fit. For cultural capital, the scale was based on the level of education of each representative of the entities: 1.Primary, 2.Secondary, 3.Technician, 4.University level, 5.Specialization/MBA, 6.Master, 7.Doctorate, and 8.Post-Doctorate. Thus, the level of education determined the scale on which the entity fit. For the share capital, we analyse the number of connections or relationships maintained by the agent with other organizations: (1) Government (2) Academy; (3) Entrepreneurs; and (4) Organized Civil Society at the levels: i. Friendship ii. Work iii. Familiar. Thus, the maximum number of relationships that an organization can maintain is 12. To calculate the scale, we divide 8 (maximum scale number) by 12 (number of relationships), we have a value of 0.67 for each relationship the agent maintains. In the end, we add up the results for each type of capital to obtain the volume of capital of each agent.

8 The data referring to this period refer to the work that the first author performed in Oliveira et al. (2020a; 2020b), and the results of which take part in this analysis. To complete the analysis of the decade, the authors of the present text extended data collection to the years 2019 and 2020, regarding COMTUR's official minutes and documents.
} 
Table 3. Chronology of institutional acts related to COMTUR in Juiz de Fora (MG) (1998-2020).

\begin{tabular}{|c|c|c|c|}
\hline Date & Normative Act & Line up & Purpose \\
\hline \multicolumn{4}{|c|}{ Moment 1- 1998-2004 } \\
\hline February 18, 1998 & Law No. 9218 & $\begin{array}{l}\text { Creates the Municipal } \\
\text { Tourism Council and the } \\
\text { Municipal Tourism Fund of } \\
\text { Juiz de Fora. } \\
\end{array}$ & It establishes the first attempt to form of COMTUR. \\
\hline August 27, 1999 & Decree No. 6512 & $\begin{array}{l}\text { Establishes the Internal Rules } \\
\text { of procedure of the body } \\
\text { (COMTUR) }\end{array}$ & $\begin{array}{l}\text { Establishes the number of directors, four of which are linked to public sector and } \\
\text { seven to civil society, adding eleven members. }\end{array}$ \\
\hline - & - & - & $\begin{array}{c}\text { Discretionary performance of tourism within the Directorate of Planning and } \\
\text { Strategic Management (DPGE) }\end{array}$ \\
\hline 2003 & $\begin{array}{l}\text { Strategic Sectoral } \\
\text { Plan for Tourism of } \\
\text { Juiz de Fora } \\
(\text { PESTJF }) * \\
\end{array}$ & $\begin{array}{l}\text { Organization of the local } \\
\text { tourist offer }\end{array}$ & $\begin{array}{c}\text { Instrument that formalized purposes and actions for the segment in the city, } \\
\text { intended to make the place a tourist destination, with itineraries and specialized } \\
\text { products, according to the "Tourism Regionalization Policy" launched at the same } \\
\text { time at the national level. }\end{array}$ \\
\hline \multicolumn{4}{|c|}{ Moment 2-2005-2010 } \\
\hline 2005 & - & - & $\begin{array}{l}\text { Discretionary performance of tourism within the Undersecretary of Industry and } \\
\text { Commerce. The sector had a tourism coordinator, } 16 \text { internal trainees and } 36 \\
\text { external trainees. }\end{array}$ \\
\hline 2008 & Municipal Law & $\begin{array}{l}\text { Secretariat of Tourism } \\
\text { Industry and Commerce }\end{array}$ & $\begin{array}{l}\text { It puts tourism as a new era, industry and commerce are traditions in the city, but the } \\
\text { goal was to bet on tourism as a new alternative to add to the development. }\end{array}$ \\
\hline December 2008 & - & $\begin{array}{c}\text { Extinction of the Secretariat } \\
\text { of Tourism Industry and } \\
\text { Commerce }\end{array}$ & $\begin{array}{l}\text { Tourism now has only two trainees and is placed as a sector of articulation without } \\
\text { execution power, thus reducing its importance in the institutional structure }\end{array}$ \\
\hline December 16, 2010 & $\begin{array}{l}\text { Law No. 12,178, } \\
\text { (repealed law no. } \\
9218 \text { of 1998) }\end{array}$ & $\begin{array}{l}\text { Municipal Tourism Council } \\
\text { of Juiz de Fora was } \\
\text { reinstituted } * *\end{array}$ & $\begin{array}{l}\text { A new bylaw has been approved. After a period of inactivity, COMTUR was } \\
\text { reestablished. }\end{array}$ \\
\hline December 16, 2010 & Lead n ${ }^{\circ} .12 .178$ & $\begin{array}{l}\text { Institutes the Municipal } \\
\text { Tourism Fund - MTF }\end{array}$ & $\begin{array}{l}\text { The MTF is a public fund associated with the tourism segment to promote the } \\
\text { development and maintenance of tourism in the municipality (PJF, 2010a). }\end{array}$ \\
\hline \multicolumn{4}{|c|}{ Moment 3-2011-2019 } \\
\hline 2013 & $\begin{array}{l}\text { Law No. } 12,812 \\
\text { (amends law no. } \\
12,178 \text { ) }\end{array}$ & $\begin{array}{l}\text { Redefines the composition } \\
\text { and roles of board members. }\end{array}$ & $\begin{array}{l}\text { "the chairman of the board should be elected alternately between the members } \\
\text { representing the private sector and the municipal government" (PJF, 2013). Civil } \\
\text { society entities were considered "representatives of the private sector". }\end{array}$ \\
\hline December 15, 2016 & $\begin{array}{l}\text { Law No. } 13,469 \\
\text { (amends law no. } \\
10,000 \text { ) }\end{array}$ & $\begin{array}{l}\text { Changes the name of the } \\
\text { current Secretariat for } \\
\text { Economic Development, } \\
\text { Labor and Generation of } \\
\text { Employment and Income - } \\
\text { SDEER to "Secretariat of } \\
\text { Economic Development, } \\
\text { Labor and Tourism - } \\
\text { SEDETTUR" }\end{array}$ & $\begin{array}{l}\text { Articulate and implement economic development policies, including trade, industry, } \\
\text { service, science and technology, tourism, work, job creation and income, the } \\
\text { incentive to small and microenterprise and individual entrepreneur, international } \\
\text { relations and research aimed at the sustainable development of the municipality. }\end{array}$ \\
\hline December 17, 2017 & - & $\begin{array}{l}\text { The statute of the MTF has } \\
\text { been established }{ }^{* * * * *}\end{array}$ & $\begin{array}{c}\text { It establishes that possible revenues will come from appropriations and } \\
\text { contributions from individuals or legal entities; transfers from the Union, state or } \\
\text { public or private entities or results of financial operations of the MTF (PJF, 2010a; } \\
\text { PJF, 2017). }\end{array}$ \\
\hline 13 November 2018 & - & Bylaw & Bylaw document has been reissued. \\
\hline September 3, 2018 & $\begin{array}{l}\text { Ordinance No. } \\
\quad 10.131\end{array}$ & $\begin{array}{l}\text { Appointment of new } \\
\text { directors }\end{array}$ & $\begin{array}{l}\text { Appoints the members of the board, with emphasis on } 17 \text { holders linked to civil } \\
\text { society. }\end{array}$ \\
\hline January 31, 2019 & Law No. 13,830 & $\begin{array}{l}\text { Creation of the Secretariat for } \\
\text { Economic Development, } \\
\text { Tourism and Agriculture } \\
\text { (SEDETA) }\end{array}$ & $\begin{array}{l}\text { Merger of the Secretariats of Economic Development, Labor and Tourism } \\
\text { (Sedettur) and Agriculture and Supply (SAA), responsible for the definition of } \\
\text { general guidelines and coordination of the formulation and implementation of } \\
\text { employment and income policies, entrepreneurship, industrial, trade, services, } \\
\text { agribusiness and tourism of the municipality. The Department of Tourism Incentive } \\
\text { (Ditur), which is responsible for planning, coordinating, promoting, disseminating } \\
\text { and supervising actions aimed at the development of the activity in Juiz de Fora, is } \\
\text { part of the portfolio. }\end{array}$ \\
\hline
\end{tabular}

* PESTJF's specific strategic lines and objectives: a) strategic lines: 1) Juiz de Fora, receptive city: develop Juiz de Fora as a tourism portal, integrating it with other cities, expanding and improving its tourism infrastructure and the professional qualification of the sector, with the specific objectives: $i$. Establish effective policies for the disclosure of Juiz de Fora; ii. Seek an integrated structure to support tourism, reinforcing the articulations between the public and private sectors; iii. Improve the competitiveness of the sector as a basis for tourism development, strengthening professional training infrastructures; b) strategic line 2: Juiz de Fora, singular, historical and cultural city: intended to value current products, diversifying services and improving their quality to consolidate the tourist destination "Juiz de Fora", with the specific objectives: i. Consolidate Juiz de Fora as a gastronomical hub, ii. Enhance the singularities of the city that give it a condition of respect for social groups; iii. Valuing local tourist products, highlighting the city at the national level; iv. Generate qualified and articulated infrastructure to support products and cultural manifestations (PJF, 2003; Oliveira et al., 2020a).

** In accordance with Article 1 of Law 12,178 of December 16, 2010, the Municipal Tourism Council of Juiz de Fora (COMTUR) is "a collegiate advisory body, of advice and inspection, aimed at guiding, encouraging and promoting tourism in the municipality of Juiz de Fora" (PJF, 2010).

*** It is noteworthy that the management of The MFT is not directly linked to COMTUR, as clarified in the following excerpt: "the MFT will be administered by the body directly related to tourism of the Municipality of Juiz de Fora, and the holder is responsible for the financial management of resources and execution of the technical and administrative tasks inherent to the Fund" (PJF, 2010a; PJF, 2017)" (Oliveira et al., 2020a: 68). 
characterized by the existence of three legal devices (Municipal Tourism Council, Municipal Tourism Fund and Municipal Tourism Plan), and markedly developed in three historical moments (or phases) in the municipality: 1) between 1998 and 2004 -institution of the theme and its introduction into the local public agenda; 2) between 2005 and 2010 - a troubled moment in which tourism gains relevance, but at the same time identifies the emptying and decommissioning of the structures and mechanisms previously created; and 3) between 2011 and 2019 reactivation of legal mechanisms and effort for the maintenance and continuity of actions, this period is the focus of our analysis. The Table 3 systematizes institutional acts and their changes related to tourism policy in Juiz de Fora (MG).

In the first period (1998 and 2004) it is seen the institution of the theme and its introduction into the local public agenda. Although at that time there was no institutionalized space for tourism within the public organization, according to the Coordinator of Articulation and Strategy of the Department of Tourism of the Municipality of Juiz de Fora ${ }^{10}$ there were employees dedicated to meet the tourism theme within the Directorate of Planning and Strategic Management (DPGE). In relation to COMTUR, as observe Oliveira et al. (2020a), in its early years, the Council did not establish a Municipal Tourism Plan or an analogous document. Despite the existence of civil public employees within the city hall dedicated to tourism, in addition to the creation of COMTUR and The MFT on February 18, 1998, few actions were carried out until 2004, and there is no documentation available on the period, with the exception of the publication of the Strategic Sector Plan for Tourism of Juiz de Fora in 2003, externally prepared by a specialized consulting team ${ }^{11}$. The Plan mentions that its implementation should be due to the implementation of 43 projects, selected among propositions of individuals and local organizations, which was not verified, and the Plan was not executed, among other factors by political discontinuity ${ }^{12}$ (PJF, 2003). On the other hand, Oliveira et al. (2020a: 68) infer that, even considering the discontinuity and non- implementation of the Strategic Sector Plan for Tourism, it "contributed to the consolidation of public institutions and equipment, such as the Juiz de Fora Convention \& Visitors Bureau (created in 2001 and still active) and Expominas Juiz de Fora ${ }^{13}$ (inaugurated in 2006)".

We see then that this period is marked by actions of relevance to tourism, such as the creation of COMTUR and MFT, in addition to the publication of a Strategic Tourism Sector Plan. In addition, tourism acts in a discretionary manner within the municipal public management, not having its own space. However, the interaction between the agents in the field occurred in a little articulated way, because there was no direct participation of public officials within COMTUR, the Plan was a parallel incitive, executed by agents outside the field.

Between 2005-2010, the second period observed, there was a troubled moment in which tourism gains relevance, but at the same time identifies the emptying and deactivation of the structures and mechanisms previously created. According to the Coordinator of Articulation and Strategy of the Department of Tourism of the Municipality of Juiz de Fora, in 2005 there were changes in management, and the tourism theme that was subordinated to the DPGE, passes to the Undersecretary of Industry and Commerce, but still without formalization, because it still has no own portfolio. Although, even if it did not have a space office, the sector had a tourism coordinator, 16 internal trainees and 36 external trainees to meet the demands of tourism in the city. During this period, it was implemented the Project "Living Juiz de Fora" with free itineraries on the weekend.

It is only in 2008 that this activity has its own office, from the creation of the Secretariat of Tourism, Industry and Commerce. Due to this fact, tourism is really inserted in the Municipal Law and gains institutional recognition and aims to generate development along with the traditional activities of the city, industry and commerce. However, according to the counselor interviewed, when there was a change in the term of office of the Mayor, at the end of 2008, the aforementioned

9 Although there is a record that in the 1970s there was an Autonomous Department of Tourism (DAT, in Portuguese acronyms), within the Municipality of Juiz de Fora in the period of government of the President Itamar Franco, there is no record of its activities. This Department worked for a while, but soon after it was extinguished (personal interview on April 8, 2016 with Coordinator of Strategic Articulation of the Department of Tourism of the Municipality of Juiz de Fora).

10 Interview held on April 8, 2016

11 The external consultancy was called Marco Apoio, and later it changes its name to Instituto Ideias.

12 On this political discontinuity of public policy, Oliveira et al. (2020a) consider that, in the municipal electoral process of 2004, the dispute between the candidate of the situation and the municipal director of planning favored the victory of a third competitor, from outside the situation, who did not follow several actions of the previous management, among them, tourism. However, it is important to consider that it cannot necessarily be affirmed that the discontinuity of public policy exclusively due to the exchange of municipal public management, since there may be policy discontinuities within the term of office of the same management, either due to lack of resources, reorientation of courses of action, priorities, among others.

13 Centro Regional de Convencões e Exposicões da Zona da Mata - Expominas Juiz. de Fora is a Convention Center administrated bv the state government of Minas 
Secretariat was extinguished, as well as the Project "Living Juiz de Fora", the sector began to have only two internal trainees and tourism is placed as a sector of articulation without execution power, reducing its importance in the institutional structure.

In this context, the Secretariat of Tourism, Industry and Commerce becomes undersecretary of Economic Development within the Secretariat of Planning and Development, where the "Tourism Center" is located. Following the Department of Planning and Development was dismembered into two folders, Planning and Economic Development, and linked to this the Department of Tourism.

In relation to COMTUR and FMT, there is a discontinuity in their operation, although they have not been officially extinguished, they simply stopped working. According to the Coordinator of Articulation and Strategy of the Department of Tourism of the Municipality of Juiz de Fora, this happens because COMTUR is gradually disarticulating and losing strength from the moment the presidency starts to be represented by a person from the municipality of Bicas (another municipality nearby), reaching the point of not working.

With this scenario of fragmentation and disarticulation of the sector, in 2009 with the aim of strengthening tourism in the city, the first Tourism Forum took place, which brought together organizations related to tourism activity to discuss the main problems and the possible alternatives. The main alternative found was the need to reactivate COMTUR/JF. It is then in December 2010, that the board is reactivated with an advisory basis, allowing agents to initiate a process of organization and articulation of the sector.

We see then that this period is marked by a conflict in the tourist field, the agents involved were questioning the relevance of tourism in the city, leading to the reduction of the available structures to the sector -extinction of the Secretariat of Tourism, Industry and Commerce, reduction of personnel, extinction of programs and disarticulation of COMTUR. But at the same time there is a movement in the field by some agents, seeking to find alternatives to recover the centrality of the theme in the context of municipal public management (bureaucratic field) (Bourdieu,
2004).

In the third period, between 2011 and 2020, the focus of analysis of this research, there is not only the resumption of actions, but also their relative continuity and stability over more than a decade. This does not necessarily mean amazing progress, on the contrary, the achievements are modest, but to some extent represent relative marginal advances in relation to the previous situation. Such achievements can be attributed, predominantly, to 2 types of factors: a) external, such as a window of political opportunity and b) internal, by certain actors and their interests and, more or less, proactive behavior. For example, regarding the first factor, it is possible to mention the reactivation of COMTUR itself in December 2010 with the explicit intention of meeting the requirements of the National Tourism Plan and the State Tourism Policy that links the transfer of resources to the municipalities the existence of a Municipal Tourism Council and a Municipal Tourism Fund proven to be active. In the specific case of the "Tourism State Policy of Minas Gerais" this is one of the requirements of the annual transfers of the Tourist ICMS ${ }^{14}$, coming from the Robin Hood law. In addition to receiving the transfer of funds, it is also required a "Municipal Tourism Plan", which was a central theme in the discussions of COMTUR in this period. Thus, the elaboration of the Municipal Tourism Plan of Juiz de Fora became the object of dispute in the field. In relation to the second factor, Bifano-Oliveira (2016), Bifano-Oliveira and Pimentel (2020a, 2020b) and Oliveira et al. (2020b) observe that there is a small group of actors, stable and reasonably cohesive, who are the effectively responsible by the main actions performed.

In addition, during this period there is the inclusion of tourism within a Secretariat in 2016, where the name of the Secretariat for Economic Development, Labor and Generation of Employment and Income - SDEER for Secretariat of Economic Development, Labor and Tourism SEDETTUR is changed. And in 2019 with the Merger of the Secretariats of Economic Development, Labor and Tourism (Sedettur) and Agriculture and Supply (SAA), tourism remains having a portfolio dedicated to it: Department of Tourism Incentive (Ditur). This was also a demand of COMTUR members, who mentioned the need for

14 Tax on Operations Related to the Circulation of Goods and Services Rendered in Interstate and Intermunicipal Transport and Communication (ICMS in Portuguese acronyms). A portion of this tax is distributed to municipalities to develop tourism activity 
Table 4. Composition of COMTUR 2011-2020.

\begin{tabular}{|c|c|c|}
\hline Period* & Number of members & Organizational Structure/Executive Board \\
\hline \multicolumn{3}{|c|}{ Phase 2011-2016 } \\
\hline 2011 a 2013 & 21 members, pursuant to Ordinance No. 7448 of February 9, 2011 & $\begin{array}{c}\text { Chair: ABAV } \\
\text { Vice-President: Tourism Course/UFJF } \\
\text { Secretary: Ditur/SDEER }\end{array}$ \\
\hline 2013 a 2015 & $\begin{array}{l}\text { The composition of the council has been expanded. } \\
\text { Specifically, } 11 \text { other entities (totaling } 31 \text { members) were } \\
\text { accepted and appointed, but in this period, } 3 \text { entities left, with a total of } \\
29 \text { participating entities. In addition, in April 2015, } 4 \text { entities come out } \\
\text { and } 3 \text { others enter, totaling, from April to December } 2015,28 \\
\text { participating entities. }\end{array}$ & $\begin{array}{l}\text { Chair: Ditur/SDEER } \\
\text { Vice-President: ABAV (until 18/03/2014), } \\
\text { and during the term was replaced by the } \\
\text { Tourism Course /UFJF } \\
\text { Secretariat: ABRASEL }\end{array}$ \\
\hline \multicolumn{3}{|c|}{ Phase 2017-2020 } \\
\hline 2015-2018 & 28 members, according to Ordinance No. 09204 of February 23, 2016. & $\begin{array}{c}\text { Chair: ABRASEL } \\
\text { Vice-President: ACRBA } \\
\text { Secretary: Ditur/SDEER }\end{array}$ \\
\hline $2018-2020$ & $\begin{array}{l}24 \text { members, according to Ordinance No. 10131, of September 3, } \\
\qquad 2018 .\end{array}$ & $\begin{array}{c}\text { Chair: DITUR/PJF } \\
\text { Vice-President: Tourism Course/UFJF } \\
\text { Secretariat: ABRASEL }\end{array}$ \\
\hline
\end{tabular}

*Note: Management 2011-2013 (from 10/02/2011 to 31/07/2013); Management 2013-2015 (from 01/08/2013 to 15/12/2015); Management 2015-2018 (from 16/12/2015 to 12/09/2018); Management 2018-2020 (from 13/09/2018 to 2020).

Source: own elaboration from the data of the minutes (2011-2020) and the PMJF (2020).

a Tourism Secretariat. It is worth mentioning that, although it is not an exclusive Secretariat of Tourism, it is an advance in relation to the activity by public management.

Thus, this period is characterized by a more frequent interaction and a more proactive interactive dynamic, with the search for common goals, by a greater willingness to collaborate among members, but this process, which is developing over the decade, is very slow. It is this interactive dynamic that we intend to analyze forward, but it is interesting to subdivide, for analytical purposes, this period from 2011 to 2020 into 2 phases: from 2011 to 2015 , and from 2016 to 2020 , which will be explored more closely below.
The opposition of the field by its main agents and their frequency

First of all, it is important to comment, in a synthetic way, how COMTUR works. Currently, the Council is linked to the Secretariat of Economic Development, Tourism and Agriculture. Its organizational structure consists of an Executive Board-composed of President, Vice-President, and Secretary-, Fiscal Committee and Members. The term of office of the Executive Board is renewed every two years, in at least one third of its full members (PJF, 2010). Currently meetings take place ordinarily 6 times a year, it is composed of a non-governmental majority, with advisory and advisory and inspection character, aimed at guiding, encouraging and promoting tourism in the municipality of Juiz de Fora (Oliveira et al., 2020a).

Graph 1. Frequency of entities for the period 2011-2015.

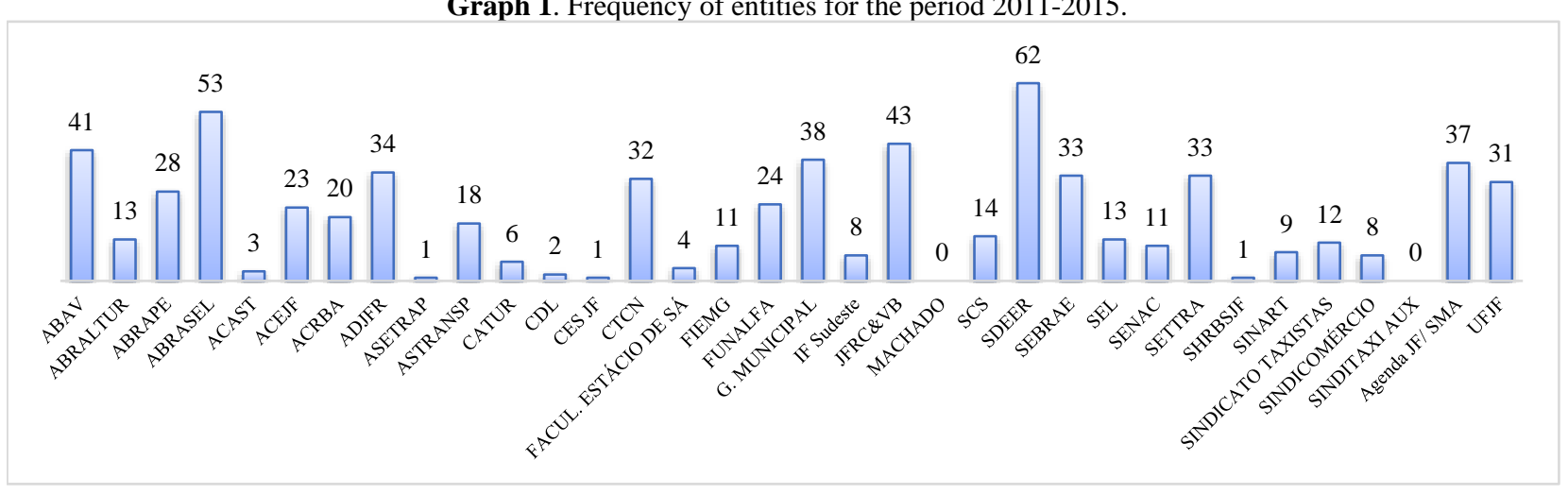

Source: Authors elaboration. 
From 2011 to 2015 , we analyzed 63 minutes to quantify the presence of each member at COMTUR meetings. The analysis was performed from the records in minutes available on the website of the Municipality of Juiz de Fora, in the webpage dedicated to COMTUR ${ }^{15}$. Thus, the presence of the members in the meetings was compared and these numbers were counted, in order to know and verify the degree of participation that competes and involves the tourist trade within the COMTUR.

From the quantification of the frequency of the members of the Council, we identified that the frequency of participation of the entities in the meetings, in general, is low (see graph 1). Of the 34 COMTUR member entities in the period analyzed, $24(70.5 \%)$ did not attend even half of the meetings held.

The entities that participate most are generally directly related to the tourist trade of Juiz de Fora, which in a way justifies their greater interest in participating in discussions about the activity. Only 10 entities attended more than half of the meetings, they are: (1) Secretariat of Economic Development Employment and Income/Department of Tourism (SDEER/Dtur) with 62 attendances; (2) Brazilian Association of Bars and Restaurants (ABRASEL) with 53 attendances; (3) Juiz de Fora and Region Convention Visitors Bureau (JFRC\&VB) with 44 attendances; (4) Brazilian Association of Travel Agency (ABAV) with 41 attendances; (5) Municipal Guard (GM) with 37 attendances; (6) Environment Secretariat (SMA) 37 attendances; (7) Juiz de Fora and Region Development Agency (ADJFR) with 34 attendances; (8) SEBRAE with 33 attendances; (9) Transport Secretariat (SETTRA) with 33 attendances; (10) Tourist Circuit "Caminho Novo" (CTCN) with 32 attendances.

As for the period 2016 to 2019 , there is institutional continuity in terms of the structures, mechanisms and policies (discretionary or not) already defined and ongoing since 2011, which represents, in a way, the maintenance and stability of the actions and provisions in progress, but also a prior structural conditioning, since the "rules" of the game are established, that is, there are criteria for the entry, permanence and participation of agents in this social sphere.

If, on the one hand, most of the rules remain identical, it is important to highlight the change of some rules in relation to COMTUR and its dynamics in 2018, after a new publication of its Bylaw. One of them is the change in the number of mandatory meetings -from 12 to 6 per year-as an internal standard for its regimentally defined operation. The justification for this change was the supposed formal difficulty to held 12 annual meetings in previous years, a requirement that is necessary for the formal adaptation of the municipality to the State Tourism Policy, which in turn, if not complied with, would result in loss of transfer of resources. This proposal was made by the representative of the Municipality of Juiz de Fora (PJF) and approved by all, without in-depth discussions.

If at first, we thought that the reduction in the number of mandatory meetings to 6 per year could have favoured the increase in the number of members' attendance at the meetings, it was found that there were low rates of participation and dispute in the governmental and nongovernmental segments, a reduction in relation to a participation that was no longer significant (Pimentel et al., 2019). According to Oliveira et al. (2020a), the percentage of participation of directors linked to the public authorities in the period from the second half of 2016 to the end of 2018, corresponded to $35.7 \%$, and the participation of civil society councillors was $43.6 \%$. That is, the directors did not attend even $50 \%$ of the meetings in the period analysed. On the other hand, the authors also identified a homogeneous behaviour of some members representing the government and civil society, which indicates the existence of cohesion in a minority group that keeps COMTUR moving (Oliveira et al., 2020a).

As noted by Oliveira et al. (2020a: 70) in addition to the use of a type of technical language that suggests the attempt to impose a point of view in addition to criticism, this poor performance is verified by the fact that:

[...] all seats available to the government, in all meetings, $35.7 \%$ were occupied; this same indicator, for civil society councillor's, corresponded to $43.6 \% ; 85.7 \%$ of the agenda points were unanimously approved and $85.7 \%$ of the deliberations turned to issues relating to Comtur and not to public tourism policy [...] another information extracted from the minutes of the meeting is that there is stability between assiduous actors in Comtur, that is, the attendance records display recurring names. It is possible to infer, therefore, that there is a nucleus - numerically much smaller than the Comtur plenary - that supports its actions. [...] 
Although the Rules of Procedure require only 6 regular annual meetings, it also requires frequent extraordinary meetings. As the object of dispute was the elaboration of the Municipal Tourism Plan, besides being a requirement for the transfer of ICMS, all the debate related to the updating of the Municipal Tourism Policy migrated to the extraordinary meetings. Another significant change was the change of individual members in September 2018, allowing representatives of their entities in the previous management (2016 to 2017) to be replaced by new representatives. Not only did the dynamics between the agents start to unfold differently, but there was a concentration of attributions and positions in the same individual, simultaneously representing different institutions (ABRASEL and DITUR/PJF).

These amendments - the Bylaw and new membersmaterialized not only in the quantity, attendance and absenteeism of the participation of members in relation to the council, but also negatively impacted the process of interaction, discussion, collective deliberation, which became more apathetic, protocol (without discussions) and merely formal, in order to approve demands, brought by municipal public management, formal adequacy to municipal regulatory requirements or higher legislation. An emblematic example can be seen in the approval process of the Municipal Tourism Plan -whose fundamental engine was the threat of suspension of transfers from SETUR/MG to PJF, made repeated times in previous years, since the existing Plan was from 2003 and this was also a mandatory requirement for the receipt of transfer of funds from the tourist ICMS.

From this finding, it can be said that Bourdieu (1993) is assertive in stating that the structure of distribution of relative power capital in a field is altered by the entry of new agents, which brings with it the change of new rules. In the case under analysis, the entry of new members takes place in September 2018, and two months later, in November of the same year, it is published the new bylaws.

But if the profile of the council and its dynamics had reduced its performance, how is it explained the publication of a Municipal Tourism Plan in 2020 , whose process predominated by the stop and go logic was stuck for more than 5 years, having started in the management of the year 2016. The replacement of the full member representative of the Dep/Tur UFJF, by his successor as full member of this institution with COMTUR, who, for own reasons personally assume the mission of completion of the Municipal Tourism Plan and is who will coordinate and that will make efforts, from the beginning to the end, to the execution and delivery of the document.

\section{Habitus, disposals and forms of action in the field}

If the documentary sources already give us the clue of a type of dynamics installed in the microcosm of the social space, the habitus, the disposal and forms of action of agents in the field may be better explored, or at least deepened, in relation to interviews and use of direct observation, by one of the authors.

Habitus refers to a process of socialization of agents and to their tacit, practical knowledge of them in relation to the way of doing, behaving and even to the cognitive schemes of their social environment. This type of tacit knowledge can be seen in two different situations in the period observed (2011 to 2019).

The first with regard to the production of a doxa (dominant view, common sense, and usually illusory) instituted around the notion of tourism of "business and events" as being the segment of greatest demand and representativeness of tourism in the city and, should therefore, be assumed as a structuring axis in terms of public policies for the sector.

Tourism in JF it is a business tourism [...] the private sector knows very well the importance of tourism as a business and not only as leisure. The city of JF is business is not leisure, no one comes here because of Halfeld Street or because of the Olympic Torch, comes to do business in the city, comes to a convention, comes to an event, a fair. So that's the profile of the city [...] The role that the focus that should be developed is to apply in events, and in the attraction of events that the city behaves for the consolidation of business tourism in the city as a city that has infrastructure for business tourism. This is the profile that the whole trade knows that we have to work within it there, work more and more business tourism (SHRBSJF).

Source of revenue within the business and events segment (CTCN).

I think it's a pretty embryonic thing yet. Stronger on the issue of events (SMA).

Business tourism, I do not see growth to do a cultural tourism, we have a lot of good and I do not see a development in relation to this (Sec Com Social).

The focus is business tourism, we have to develop more of this, I fear a good infrastructure of hotels and restaurants (ADJFR).

So there is a focus that is business tourism and events, which is the role that Juiz de Fora's tourism is adopting today, so generally that's it, the Convention Bureau works with it, the university, the focus of it, I won't say it's the main focus, but it all leads to business tourism and events, the developments all lead to this, you see hotels are being building and event 
spaces in the city are growing so rapidly, apart from the performance that the city of JF gives to this segment of tourism (CATUR).

It is important to note how uncritically this vision -strongly headed and defended by representatives of the private sector- is spontaneously assimilated by the other agents, even in the absence of any confirmation, data or related fact; but so merely by the principle of verification (subjective and singular tacit knowledge) that commercial representatives are the "tourists" who occupy the city's hotels the most.

Although there are indications that it is business tourism that predominates in the city, as pointed out in the survey 16 "The tourist that the city has, the city that the tourist wants" coordinated by Professor Marcelo Carmo Rodrigues of the tourism bear of the Federal University of Juiz de Fora (UFJF) in 2016, other studies reveal that the main reason for the arrival of tourists to the city is to visit "friends and relatives" 17 (SETUR, 2017). A significant part of these tourists is linked to the student flow, or to the microregional commuting, or the flow of weekend tourists, which seem to be completely ignored. As mentioned in the Municipal Tourism Plan (2020: 55), these two studies on the profile of tourist demand in the city point to an advance in the attempt to characterize the tourist, but "it is noticeable the lack of constant monitoring regarding the profile of demand and its peculiarities. In addition, it is mentioned the lack of a single methodology for research, allowing a comparison of parameters".

An even more important bottom issue would be pertinent to be asked: about the disjunctive between business tourism versus events; and another even more important about the very idea of specifying in a univocal way a type of tourism profile for the city. In this way, is the establishment of a public policy exclusively oriented to business tourism and events the appropriate way? Meanwhile, visions considered peripheral perhaps more by the absence of their defenders in the social space of the council than by a factual foundation- such as historical-cultural and gastronomic tourism (Oliveira et al., 2020a), may be more unusual due to the very lack of development of tourism products and services by the private sector (Pimentel \& Oak, 2020), which, in turn, demands a public policy to create subsidies for its inefficiency.

Today there is a lack of an identity of the attraction, valuing the attraction so that it is experienced by the community. We focus only on business tourism and events. There is a lack of better communication between sectors. We have much more to offer" (ABRALTUR).

Now tourism, in reality I see it as a tool for development, it generates jobs, hospitality, restaurant, service, all this, tourism is a development tool of the city, has to be much better explored. The relationship of the city with business tourism is already well fostered, I think Comtur already works this idea, but I think it can work much more, not only as business tourism, but as leisure tourism too [...] and maybe even in the tourist attraction, not business, leisure tourism, the person come here and have what to do, even have, we have enough things, we have the Brewery Circuit, it has the JF Sabor, it has other things that is leisure for people and maybe is little publicized out of Juiz de Fora (SINART).

[...] that society can turn this value into JF that can yes, transform tourist products, as for example the issue of beer is one, we can turn beer into a tourist product of the city, it has not yet reached that point, but can, the way is this, make touristic the beer, as well as the cultural heritage of Juiz de Fora, how many are the museums of Juiz de Fora, the juizforano does not know, the architectural heritage of Juiz de Fora which is an important heritage, people come from outside and is surprised by Juiz de Fora and the juiz-forano this has already become a stain on his vision, and he cannot see the beauties of the galleries that cross the center of the city and, a trade completely distinct from the rest of the country, which is a street trade, so vigorous, so strong, and so concentrated [...] I mean, we have some features that are so cool, that we could sell it better, and we can't (ABRASEL). [...] I think it's what shouldn't aside, that it would be of JF's identity that so it gets lost a little, in my opinion okay, and tourism should explore more of this, which is cultural tourism, it's historical tourism, the material and immaterial heritage that we have and the identity of JF should not be left aside, and this should also be a complement to business tourism and events since it is the focus of JF today. There is also the German issue, of craft beers that is not being taken still very well positioned, of course there is already a wonderful work on this, but I think the trade the government should have eyes, see better this segment (CATUR).

In this away, this little divergence makes it difficult for actors to enter into a consensus (Pimentel, 2018) on how to act and how to design strategies to promote tourism more efficiently in the city. This is evidenced in the speech of some councilors interviewed, who highlight the need for a global vision of the destination, which includes an integration of all sectors in search of a common goal that is tourism development in the city.

16 According to the results of this survey, the majority of tourists from Juiz de Fora go on business (53.5\%), visit the city for family gatherings (16.2\%), for social, cultural, technical-scientific and sporting events (7.8\%): health (4.5\%): leisure (7.4\%); education and education (3.1\%) and others $(7.5 \%)$.

17 In this study of the Setur/MG, the results indicated that $40.6 \%$ of tourists travel to Juiz de Fora to visit friends and relatives, and $19.8 \%$ business, followed by $14.6 \%$ for health reasons. 
But I think the biggest difficulty and the biggest obstacles to this convergence is exactly that, whether it's this view that is very focused on the entity itself, and when you're in a sphere of this governance I think you talk about a unit of analysis and development much greater than the very interest of your specific entity. Understood? So, if we go to COMTUR to deal with issues only the Convention, which concerns the capture of events and there is a good relationship with the hotel and events network installed in the city we will lose the dimension of other things, if we deal with issues only related to issues of gastronomy for example, we will miss other opportunities. So, I think it's getting out a little bit, getting out of the box, getting out of the box, thinking more integrated and within your own interests, is giving up a little vanity (ABRASEL).

Everyone wants the tourism to develop, that JF effectively become a popular destination, [...] at the same time there is a huge point of divergence that prevents these people from feeling together, organizing, establishing policies, so everyone wants but, and I participate in many meetings and groups related to the tourism of Juiz de Fora, everyone wants tourism to arrive, go down, appear in the city as the salvation of the crop, as the chicken of the golden eggs, but in counter starting I see that a point of divergence that is all actors involved in the meetings of which I attend, in the end I realize that they are very concerned about benefiting their own business. So [...] It's a nonsense, I want tourism, but effectively I want this tourism to settle, but I don't want it to bring me investments, I want my company to always benefit, so this is really a bottleneck, in development, in the establishment of tourism in the city (UFJF/Deptur).

[...] as the person is focused on self-interest. Understood? He does not understand [...] that I work for the collective and as a consequence I will earn the profit. Understood? Then there are many who cannot understand why I will work for the collective [...] (SDEER /Dtur).

A second important point to be addressed in the issue of habitus is the willingness of agents to think and act in a certain way (Pimentel, 2014; BifanoOliveira; Pimentel, 2016; 2020a; 2020b). For example, we have identified that agents that make up the same sector tend to have the same view. And as the idea (taken even as a value) of competition is naturalized and mobilized by the agents of the segments (regardless of specific enterprises) linked to private initiative, whether through metrics, forms of evaluation or distribution of resources, we see that, on the other hand, segments of organized civil society tends to orient itself towards social inclusion, while the public sector is tended to be oriented to (uncritical) compliance with norms (even those ethically questionable). Although the results show the same disposition related to the same sector, we identified that the economic aspect of tourism is the view partitioned by all of them (see Figure 2). Spatial and identity proximity tends to cause agents to acquire the same disposition and reference schemes (habitus) for action.
Figure 2. Layout in the field.

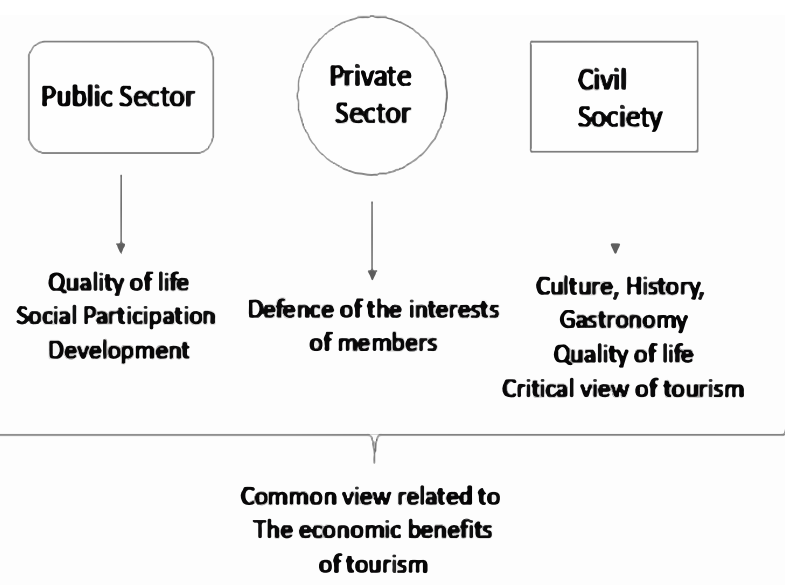

Source: own elaboration from the research data.

However, provisions do not necessarily imply automatism in action. Despite this divergence between the agents, according to Oliveira et al. (2020b), there is a convergence in the interviewees' statements regarding the function associated with COMTUR, which Bourdieu calls nomos, and which means legitimate procedural forms and rules by which one can and must act. The first question, in this context, concerns the legitimacy of this social space (COMTUR), and the ways in which one can act in it, and, in turn, that it can act in other broader social spaces. For the interviewed agents, the role of the council is of articulation, organization of efforts of the members of the chain, and development of proposals and actions to be undertaken in an integrated way. They also mention that it is up to COMTUR: (1) to think about public policies, (2) consolidate the Municipal Tourism Plan, (3) advise local authorities and (4) consolidate itself as the sphere of social participation and control.

[...] Comtur has recently improved its performance, as structuring actions, which required substantive time and energy, and now have consolidated. This is the completion of the first stage of the municipal tourism plan, after two years of work, and the realization, on July 3, 2019, of the " 1 st Forum for Tourism Management and Events of Juiz de Fora" and region, which, among other actions, published the diagnosis that will underpin the plan (Oliveira et al., 2020b:19).

This goes against the results of our research, which identified that despite the various problems within COMTUR -slowness, little concrete action, search for particular interests on collectives- we can highlight in the statements of the counselors the perception of an attempt to make things better. There is a "will" on the part of some entities, especially those related to the tourist trade, to carry forward the work that has been built within 
the council, as they themselves mentioned, it as a slow process, but that is gradually improving.

The point of convergence is that everyone wants the Municipal Tourism Plan to be reviewed, everyone knows the needs of the city, everyone is supporting that COMTUR is deliberative, everyone is willing to work to create tourism projects. Understood? Everyone who is there believes in the potential of the entity, but I think they commit little yet as an entity. Understood? (JFRC\&VB).

The COMTUR is as follows, I think it still has little low representation in the sense of participation of the entities in meetings, it is a monthly meeting, and sometimes, I think so, there is little talk, now that there are some initiatives that seems to give some result [...] (JFRC\&VB).

[...] so I think today it would be the great difficulty in working for the sake of fate, not for each one. But so, we are trying, the entities are isolated, but they are trying (SDEER/Dtur). [...] that does not give anything, really, a discussion of an hour and a half, two empty hours that does not give, has no concrete actions [...] And I think COMTUR is not yet so, but it is starting to improve, the last meetings have been much better, already have projects, already have a perspective (JFRC\&VB).

Sometimes the desire is development but miss in the time of doing, but I have seen in a very positive way the Council, despite these difficulties, I see in a very positive way [...] the participation despite being around $30 \%$ of the group, 35, 40\% who actually participates in the Council, I think it is a relatively high number, I see councils that does not have the same participation, it is a council where in fact the ideas are agreed, are built, it is not a council that is there for form, and to refer to any idea, is a council that is there to debate, build, discuss, this I see in a very positive way and a point of convergence (ABRASEL).

The importance of the nomos observed in the second period of analysis (2016-2020), is that, unlike the previous period, in which COMTUR was in the process of legitimization, already in this second moment of the decade under analysis, these mechanisms are legitimized. Therefore, there is no question about the view that tourism actions should pass through it. Thus, and together with the configuration of agents, the tacit support the established doxa, the personal performance of certain agents, and the "external" demand that generates an imperative the need to have a tourism plan, generated between 2016-2020 a mobilization -superior to the centrifugal force of the provisions of each class of agents- around the elaboration and construction of the Municipal Tourism Plan, which is considered in this work as the object of "dispute" in the field, in this period of analysis.

The question lies not in terms of whether or not to make the plan, but how it should be done. Once in accordance with the imperative need to prepare the Plan for the transfer of ICMS funds, as we mentioned earlier, the agents expose the desire to consolidate the Plan in order to reconcile efforts and create a direction for COMTUR actions aimed at the real development of tourism in the city, since this policy will direct the common understanding (doxa), rules (nomos) and practices (habitus) imposing a view of the world, overcoming the individualistic views that aim at the benefit of the entity itself, as mentioned by the interviewees.

However, we ask what the real benefit of the transfer of the ICMS fund would be, since as mentioned by Oliveira et al. (2020a), the money coming from ICMS does not go to the MTF, it goes directly to the public account, and the tourism sector often does not benefit from this budget.

From the analysis of the minutes and official documents that regulate COMTUR, we can identify that there is little participation regarding attendance in the council, in addition to changes in the regulation that imply a lower interaction and discussion between the agents that compose it. On the other hand, when we interviewed the counselors, we realize that, even though there is a perception of a slow process, with few concrete actions, they indicate an attempt and a willingness of those who actually participate in carrying out some initiatives.

If [x] didn't get to do it, it wouldn't come out, because no one has the technical capacity to do so, apart from the lack of capacity coupled with the dispersion of interests and lack of commitment would not allow it to do so. The imposed "need" externally by SETUR opened a window of opportunity that allowed the mobilization around this, which can only be possible also by the internal work of leaders [of the UFJF member] to internally mobilize the efforts [...] (DEPTUR/UFJF).

As Oliveira et al. (2020a) mentions the councilors recognize a slow maturation, which led to the materialization of actions (Tourism Website, diagnosis of the Municipal Plan, $1^{\text {st }}$ Forum of Tourism Management and Events of Juiz de Fora and Region, and a synergy in the productive chain of event tourism). However, this process is still marked by contradictions, since despite the 33 extraordinary meetings focused exclusively on the discussion of The Plan in 2017 and 2018 (Oliveira et. al, 2020a), it was only prepared and published according to the action of a very small group of agents, with emphasis on the individual performance of certain agents, around which it turned its elaboration. In other words, if it depended on the debates and the articulation between the members of COMTUR, the Plan, materialized in a physical document, would nevertheless be an unfulfilled will. 
Graph 2. Capital volume of entities directly related to tourism*

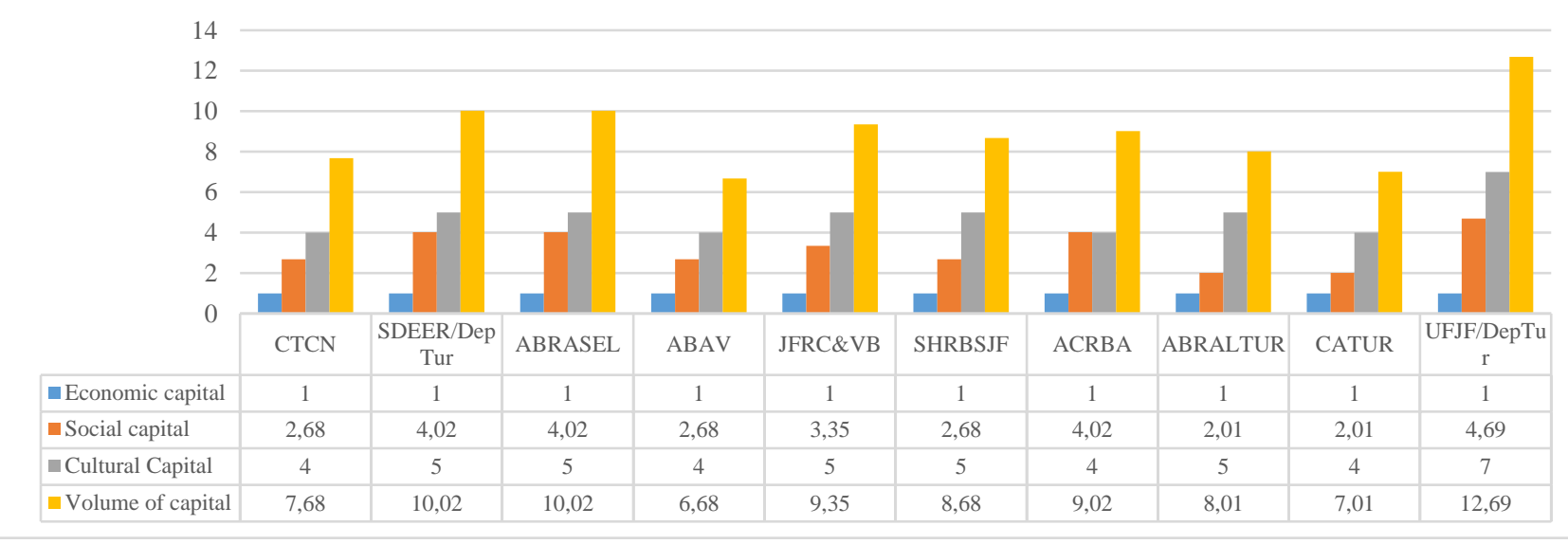

* In accordance with Article 1 of Law 12,178 of December 16, 2010, the Municipal Tourism Council of Juiz de Fora (COMTUR) is "a collegiate advisory body, of advice and inspection, aimed at guiding, encouraging and promoting tourism in the municipality of Juiz de Fora" (PJF, 2010).

Source: own elaboration from the research data.

The distribution of capital, the position of the agents and their capacity to take action in the field.

In order to identify those agents with greater power of influence in the tourist field of Juiz de Fora, we verified the position of each of them in the field under analysis. Graph 2 shows the volume of capital of entities directly related to tourism during the 2015-2018 COMTUR management period, demonstrating which agents have a higher volume of capital, that is, a privileged position in the tourist field of Juiz de Fora.

The individual agents with the highest volume of capital are respectively, the Department of Tourism of the Federal University of Juiz de Fora (UFJF/DepTur), with 12.69 volume of capital (VC), a federal public authority but which is part of the local scenario -within the scope of the Municipal Tourism Council, for example- as a representative of organized civil society ${ }^{18}$; the Department of Tourism of the City Hall of Juiz de Fora (SDEER/DepTur), with 10.02 (VC), representing the local public sector; and the Association of Bars and Restaurants (ABRASEL), tied with 10.02 (VC), followed by Juiz de Fora and Region Convention Visitors Bureau (JFRC\&VB), with 9.35 (VC) and the Brazil Germany Cultural and Recreational Association (ACRBA), with 9.02 (VC).

According to Bourdieu (2004), the agents are distributed in the social space, first according to their volume of capital, and according to the relative weight of the different species of capital.
Capitals confer a power in the field, and their distribution constitutes the same structure of the field, which is given by the position (Bourdieu, 1993). Thus, the capitals will determine the positions in the field of agents, as well as their strength and their strategies.

In this sense, if analyzed separately, the three agents with higher $\mathrm{VC}$, and that represent the different sectors -public (SDEER/DepTur), private (ABRASEL) and organized civil society (UFJF/DepTur) - we identify that they are rightly the agents who most occupied the posts of the Executive Board of COMTUR from 2011 to 2019, keeping always at the heart of the debate. This data can be verified in the table 3 (Composition of COMTUR 2011-2020), previously presented, in it we identify that in all four analyzed managements the SDEER/DepTur always took part of the Executive Board, while ABRASEL and UFJF/DepTur were part of three administrations (see table 5). The other entities that formed the Executive Board during this period were ABAV (2 managements) and ACRBA (1 management).

Table 5. Composition of the Executive Board 2011-2020.

\begin{tabular}{|c|c|c|c|}
\hline $\begin{array}{c}\text { Management } \\
\text { Period }\end{array}$ & Presidency & $\begin{array}{c}\text { Vice } \\
\text { presidency }\end{array}$ & $\begin{array}{c}\text { Executive } \\
\text { Secretariat }\end{array}$ \\
\hline $2011-2013$ & ABAV & UFJF/DepTur & SDEER/DepTur \\
\hline $2013-2015$ & SDEER/DepTur & $\begin{array}{c}\text { ABAV - } \\
\text { UFJF/DepTur }\end{array}$ & ABRASEL \\
\hline $2015-2018$ & ABRASEL & ACRBA & SDEER/DepTur \\
\hline $2018-2020$ & SDEER/DepTur & UFJF/DepTur & ABRASEL \\
\hline
\end{tabular}

Source: own elaboration from the research data. 
As can be seen, the institutional agents that occupied a prominent position as members of the Executive Board of COMTUR, over the decade (2011-2020), were practically the same, basically changing the position in relation to the composition of said board, being: ABAV, ACRBA, ABRASEL, SDEER/DepTur and UFJF/DepTur, especially the latter three, either by the how many times, or by their qualified participation (Pimentel et al., 2019; 2020). Thus, there seems to be a concentration of decision-making positions in the same actors. In addition, these agents are those who, in general, have the highest volume of capital (which even suggests the fact that they were selected, in voting, at each election, for the occupation of these positions). Finally, it is important to mention the relative importance of its participation, whether nominal or qualified in the interactive processes unfolded in this social space.

Regarding the frequency of participation of agents, in the period from 2011 to 2015, we see that SDEER/Dtur (62 attendances) and ABRASEL (53 attendances), were the entities that most participated in the meetings, followed by the Convention Visitors Bureau with 44 attendances and $\mathrm{ABAV}$ with 41 attendances. In the period from 2016 to 2020 , it is verified that the same are the entities with the highest volume of nominal participation. In addition, the studies by Pimentel et al. (2019; 2020) distinguish between nominal participation, which concerns the number of times an agent has attended meetings throughout the year, and qualified participation, which refers to the interventions, debates and proposals made by each agent, in meetings throughout the year.

Qualified participation seems to be a relevant indicator of the agents' ability to work in the field, because when data from the interventions made by the agents, are crossed with their achievements, it is observed that there is again an overlap between volume of capital, presence in management positions, greater frequency in meetings and qualified interventions, with proposals made and executed.

In summary, (a) there is a tendency to low participation of COMTUR members, generally with an average of less than $50 \%$ of meetings, (b) the most frequent agents are those occupying positions on the board and/or the MTF, (c) the agents with the highest volume of capital are the most participatory, formally and qualified, and (d) the agents with the highest volume of capital and the highest qualified participation are the most influential in the results of the interactive dynamics of the field (Pimentel et al., 2019; 2020).

Thus, we identify that the agents with the highest volume of capital and, therefore, with greater power in the field, are the ones who can influence and conduct discussions and debates, so that their proposals are kept on the agenda. Thus, as Bourdieu (1993) mentions, the space of positions tends to command the space of taken positions. Meanwhile, the other actors often seek to resume the themes of their interest and do little to involve in the discussion of other topics. However, the more global understanding of the field goes through habitus, which in the case observed, is perhaps best learned by the broader mental schemes, actions and predispositions wrapped by the cleavages of segments (or "class").

\section{Final considerations}

According to Bourdieu, in the social field the actors who have a privileged position, given the amount of capital, determine the rules of the game according to their interests. These actors tend to conserve social structures, so that their positions in the field do not change. This relationship is guided by the habitus of the field, which translates into the way of thinking, feeling and making of agents, conserving or reproducing structures. Thus, Bourdieu's theory of social fields helps to understand the relations of power and domination, which produce social structures and relationships. In addition, it allows to identify an active agent capable of transforming the structures and relationships of domination.

Thus, from the analyzed data, we verified that the entities that most participate in the meetings and their respective volumes of capital are directly related to the proposals that are executed. Confirming our assumption that the agents with more power tend to be those who, in a way, guide the local tourist context, leaving little space for the effective action of other agents, even if this action occurs in supposedly democratic contexts. That is, the entities with the most power in the field are those that have the greatest influence, which guide the local tourist context according to their perceptions. The other entities are supporting in the tourist scene of the city.

The evidence points to a direct relationship between the volume of capital of the agents, their degree of participation in the meetings and the tendency to approve and execute the proposals made by the agents with the highest volume of capital. In summary, despite a supposed openness 
in terms of the possibility of action, manifestation and participation in democratic contexts and spaces such as municipal councils, it is suggested that the agents with the highest volume of capital tend to be those who, in a way, participate more in the actions and achievements of this sphere and, in this sense, are more likely to guide the local tourist context, in opposition to the performance of the other agents, in general, less participatory, and, in particular, with lower qualification in their participation, which makes it, therefore, more limited.

\section{Acknowledgement}

This article is partially based on the results of 2 surveys previously carried out: one conducted between 2014-2016, supported by the Dean of Research/PROPESQ - UFJF (no. 31,968 PROPESQ/UFJF), providing material resources (equipment and costing) and scholarships (BIC), and the National Council for Scientific and Technological Development/CNPq, through PIBIC scholarship; and a second study, conducted between (2017-2019), which was supported by the Research Support Foundation of the State of Minas Gerais/FAPEMIG, through the granting of Scientific Research (IC) scholarships and financial resources (APQ-02693-16 process). These studies are part of a research program developed by the Economic and Social Observatory of Tourism/OESTUFJF (CNPq) on public policies in tourism in Juiz de Fora, in the state of Minas Gerais. It is worth mentioning to thanks the IC fellows (UFJF, $C N P q, F A P E M I G)$, that contributed at some point, in the collection of bibliographic materials or in the collection of empirical data.

A preliminary version of this work was presented by Pimentel, T.D. Bifano-Oliveira, M.C.; Carvalho, F.C.C. (2016). Conselhos Turísticos. Gestão Democrática? Uma Análise do Conselho Municipal de Turismo de Juiz de Fora (2011-2015). Proceedings of the XIII Annual Seminar of the National Association of Tourism Research and Graduate Studies ANPTUR. São Paulo: ANPTUR [ISSN 2359-6805]. This article revises the study by adding data from 2016 to 2020, maintaining, however essentially the same argumentation line.

\section{References}

Abramovay, R. (2001). Conselhos além dos limites. Dossiê Desenvolvimento Rural. Estud. av., 15(43), 121-140.

Bifano-Oliveira, M. D. (2016). Acción Colectiva en el Campo Turístico y su influencia en la Agenda de Políticas Públicas en Juiz de Fora/Brasil y Mazatlán/México (p. 242). Unpublished Master's Thesis. Faculty of Economic and Social Sciences, Autonomous University of Sinaloa, Culiacán Sinaloa.

Bifano-Oliveira, M. C. B., \& Pimentel, T. D. (2016). El Campo Turístico de la ciudad de Quito (Ecuador): un análisis del capital de sus agentes y de la (posible) acción colectiva sobre las políticas de turismo como objeto de disputa. Investigaciones turísticas, (6), p. 183-209.

Bifano-Oliveira, M. C. B., \& Pimentel, T. D. (2020a) A influência da posição dos agentes na elaboração de políticas públicas de turismo em campos turísticos: uma perspectiva comparada na América Latina. POLIS, 57, p.185-210.
Bifano-Oliveira, M. C. B. De; \& Pimentel, T. D. (2020b.). Volume of capital and collective action in tourism fields: a comparative perspective in Latin America. In: Koscak, M.; O’Rourke, T. Ethiacal and responsable tourism: Managing sustainability in local tourism destinations. Ney York: Routledge.

Bourdieu, P. (1983). Algumas Propriedades sobre os Campos. In: Ortiz, R. Questões de sociologia. Rio de Janeiro: Marco Zero, 89-94.

Bourdieu, P. (1989). O Poder Simbólico. Lisboa: Difel.

Bourdieu, P. (1990). Espaço social e poder simbólico, pp.149-159. In: Bourdieu, P., Coisas Ditas. São Paulo: Brasiliense.

Bourdieu, P. (1993). Interview with Pierre Bourdieu. La lógica de los campos. Zona Erógena, 16, p. 1-14, 1993. Available at: http//www.educa.ar.

Bourdieu, P. (1996). Razões Práticas: Sobre a teoria da ação. Campinas, São Paulo: Papirus, 1996.

Bourdieu, P. (2001). Poder, Derecho y Clases Sociales. España: Desclée de Brouwer.

Bourdieu, P. (2004). From the King's House to the Reason of State: A Model of the Genesis of the Bureaucratic Field. Constellations, 11, 16-36. DOI: $10.1111 /$ j.1351-0487.2004.00359.x

Gomes, E. G. M. (2015). Conselhos gestores de políticas públicas: aspectos teóricos sobre o potencial de controle social democrático e eficiente. Cadernos EBAPE.BR [online]. 4(13), 894-909. https://doi.org/10.1590/1679-395123196.

Gonh, M. G. (2011). Movimentos sociais na contemporaneidade. Revista Brasileira de Educação, 47(16), 333-363.

Gurgel, C.; \& Justen, A. (2013). Controle social e políticas públicas: a experiência dos Conselhos Gestores. Revista de Administração Pública [online], 2(47), 357-378. https://doi.org/10.1590/S003476122013000200004

IPEA - Instituto de Pesquisa Econômica Aplicada. (2012). O Conselho Nacional de Turismo na Visão de seus Conselheiros. Relatório de Pesquisa: Projeto Conselhos Nacionais: perfil e atuação dos conselheiros. Governo Federal. Brasilia.

Kliksberg, B. (1998) Seis tesis no convencionales sobre participación. Instituiciones y Desarollo.

Kronemberger, T. S. (2016). Os conselhos municipais na prática: quais limitações? In: Tenórı, F. G.; Kronemberger, T. S. Gestão social e conselhos gestores. v. 3. Rio de Janeiro: FGV.

Lima, J. A.; \& Brito, M. de S. (2021). Conception of Social Management and Deliberative Citizenship in the Assessment of Social Control of the Municipal Council of Education of Grajaú - MA. Research, 
Society and Development, [S. 1.], 6(10), DOI: $10.33448 /$ rsd-v10i6.13440.

Marques, D. \& Machado, C. A. M. (2014). Democracia e desigualdade nas Ciências Sociais brasileiras. Anais... IX Encontro da Academia Brasileira de Ciência Política [ABCP]. Brasília, DF.

Mata, G. M. F. Da. (2016). Conselhos Gestores como Mecanismos de Controle: Uma Análise em Destinos Turísticos (Master Thesis). Universidade Federal de Viçosa. Viçosa, MG.

Da Mata, G.M.F.; Pimentel, T.D.; \& Emmendoerfer, M.L. (2018). Teoria do campo social e políticas públicas: o caso do Conselho Gestor de Turismo de Juiz de Fora, MG, Brasil. Revista Rosa dos Ventos Turismo e Hospitalidade 10(2), 332-354, http://dx.doi.org/10.18226/21789061.v10i2p332

Nóbrega, W. R. M.; \& Figueiredo, S. J. L. (2014). Turismo e Gestão Pública: uma Avaliação das Instâncias de Governança no Oeste do Estado do Pará. In: Pimentel; T. D.; Emmendoerfer; M. L.; Tomazzoni; E. L. (Orgs.). Gestão Pública do Turismo no Brasil? Teorias, Metodologias e Aplicações. 1ed.Caxias do Sul - RS: EDUCS, v.1, 360-396.

Oliveira, V. C. S. E.; Teixeira, I. B.; Ferreira, V. C. P.; Pimentel, T. D. (2020a). O Papel do Conselho Municipal de Turismo na Cadeia Econômica do Turismo em Juiz de Fora/MG. RECAT - Revista Eletrônica Ciências da Administração e Turismo, (8), 57-75.

Oliveira, V.C.S.E.; Avelar, K.M.; Almeida Junior, C.R.; Ferreira, V.C.P.; Pimentel, T.D. (2020b). Representações Sociais sobre o Conselho Municipal de Turismo de Juiz de Fora, MG. Cultur: Revista de Cultura e Turismo, (14), 1-28.

Oliveira, V.C. Da S.E. (2009). Sociedade, Estado e Administração Pública: análise da configuração institucional dos conselhos gestores do município de Lavras - MG. (Doctorate Thesis). Universidade Federal de Lavras, UFLA, Brasil, 2009.

Paes De Paula, A. (2008). Por uma nova gestão pública. São Paulo: Editora FGV.

PJF - Prefeitura de Juiz de Fora. (2020). Plano Municipal de Turismo de Juiz de Fora.

PJF - Prefeitura de Juiz de Fora.(2003). Plano Estratégico do Turismo de Juiz de Fora.

PJF - Prefeitura de Juiz de Fora. (2010). Conselho municipal de Turismo. Regimento interno.

Pimentel, T.D. (2012). Espaço, Identidade e Poder: esboço de uma teoria morfogenética e morfostática para a sociologia das organizaçôes. 470p. (PhD Thesis). Universidade Federal de Juiz de Fora, Programa de Pós-Graduação em Ciências Sociais. Juiz de Fora, Minas Gerais.
Pimentel, T.D. (2014). Bourdieu, campo turístico y sus implicaciones para la gestión de los destinos turísticos. VI Congreso Latinoamericano de Investigación Turística, 1-8.

Pimentel, T.D. (2019). Uma Perspectiva Sociopolítica para os Estudos em Turismo. Anais Brasileiros de Estudos Turísticos - ABET, 3(8), 26-31. DOI: 10.34019/2238-2925.2018.v8.14070.

Pimentel, T.D.; Carvalho, F.C.C. (2020). Autoavaliação Do Grau De Desenvolvimento Da Oferta Turística Com Base Em Seus Recursos, Atrativos e Produtos Turísticos. Rosa dos Ventos, 1(12), 4380 .

Pimentel, T.D.; Carvalho, F.C.C.; Oliveira, M.C.B.; Feres, E.M.L. (2019). Entre a Formalidade e a Efetividade: A Dinâmica da Participação Social no Ciclo Político de um Conselho Gestor de Turismo em Juiz de Fora/MG. RIGS - Revista Interdisciplinar de Gestão Social, (8), 117-142.

Pimentel, T.D.; Carvalho, F.C.C.; Oliveira, M.C.B.; Feres, E.M.L. (2020). Between formality and effectiveness: The dynamics of social participation in the political cycle of a tourism management council in Juiz de Fora/MG. Journal of Multidisciplinary Academic Tourism - JOMAT, (5), 81-94.

Tenórı, F.G. (2008). (Re)Visitando o Conceito de Gestão Social. In: Silva Jr., J.T.; Mâsih, R.T.; Cançado, A.C.; \& Schommer, P.C. Gestão Social: práticas em debate, teorias em construção. $1^{\mathrm{a}}$ Ed. Vol 1. Fortaleza: Imprensa Universitária. 248p. Cap. 2, p.39-60, 2008 .

Thiry-Cherques, H.R. (2006). Pierre Bourdieu: a teoria na prática. Revista de Administração Pública $R A P$, Rio de Janeiro (RJ), 1(40), 27-55.

Unıversidade Federal de Juiz de Fora. (2016). O turista que a cidade tem, a cidade que o turista quer. Tabulação e análise de dados de projeto.

Vandenberghe, F. (2010). Teoria social realista. Um diálogo franco-britânico. Minas Gerais: UFMG. $365 \mathrm{p}$.

Vandenberghe, F.; \& Veran, J. (Org.) (2016). Além do habitus Teoria social pós-bourdieusiana. 1. ed. Rio de Janeiro: 7 Letras. v. 1. 215p.

Wacquant, L. J. D. (2002). O legado sociológico de Pierre Bourdieu: duas dimensões e uma nota pessoal. Ver. Sociologia política, Curitiba, 19, 95-110. 


\section{APPENDIX}

Table 6. Total Meetings held between February 2011 and December 2020

\begin{tabular}{|c|c|c|c|c|c|c|c|c|c|c|}
\hline Period & 2011 & 2012 & 2013 & 2014 & 2015 & 2016 & 2017 & 2018 & 2019 & 2020 \\
\hline January & - & $\begin{array}{l}\text { Day } 31 \text { - } \\
\text { Ordinary }\end{array}$ & $\begin{array}{l}\text { Day } 30 \text { - } \\
\text { Ordinary }\end{array}$ & $\begin{array}{l}\text { Day } 30 \text { - } \\
\text { Ordinary }\end{array}$ & $\begin{array}{l}\text { Day } 28 \text { - } \\
\text { Ordinary }\end{array}$ & - & Day 26-Ordinary & - & - & - \\
\hline \multirow{4}{*}{ February } & $\begin{array}{l}\text { Day } 01 \text { - } \\
\text { Ordinary }\end{array}$ & \multirow{4}{*}{$\begin{array}{l}\text { Day 29- } \\
\text { Ordinary }\end{array}$} & \multirow{4}{*}{$\begin{array}{l}\text { Day } 28 \text { - } \\
\text { Ordinary }\end{array}$} & \multirow{4}{*}{$\begin{array}{l}\text { Day } 27 \text { - } \\
\text { Ordinary }\end{array}$} & \multirow{4}{*}{$\begin{array}{l}\text { Day } 27 \text { - } \\
\text { Ordinary }\end{array}$} & \multirow{4}{*}{$\begin{array}{l}\text { Day } 17 \text { - } \\
\text { Ordinary }\end{array}$} & Day 02 - Extraordinary & \multirow{4}{*}{ Day 21 - Extraordinary } & \multirow{4}{*}{$\begin{array}{l}\text { Day } 28 \text { - } \\
\text { Ordinary }\end{array}$} & \multirow{4}{*}{$\begin{array}{l}\text { Day } 12 \text { - } \\
\text { Ordinary }\end{array}$} \\
\hline & $\begin{array}{c}\text { Day } 10- \\
\text { Extraordinary }\end{array}$ & & & & & & Day 09 - Extraordinary & & & \\
\hline & $\begin{array}{l}\text { Day } 10 \text { - } \\
\text { Ordinary }\end{array}$ & & & & & & Day 16 - Extraordinary & & & \\
\hline & $\begin{array}{c}\text { Day } 16- \\
\text { Extraordinary }\end{array}$ & & & & & & Day 23 - Extraordinary & & & \\
\hline \multirow{4}{*}{ March } & \multirow{4}{*}{$\begin{array}{l}\text { Day 16- } \\
\text { Ordinary }\end{array}$} & \multirow{4}{*}{$\begin{array}{l}\text { Day 29- } \\
\text { Ordinary }\end{array}$} & \multirow{4}{*}{$\begin{array}{l}\text { Day 26- } \\
\text { Ordinary }\end{array}$} & Day 18 - & \multirow{4}{*}{$\begin{array}{l}\text { Day } 26 \text { - } \\
\text { Ordinary }\end{array}$} & Day 16- & Day 15 - Ordinary & \multirow{4}{*}{ - } & \multirow{4}{*}{ - } & \multirow{4}{*}{ • } \\
\hline & & & & Ordinary & & Ordinary & Day 09 - Extraordinary & & & \\
\hline & & & & Day 31 - & & Day 24 - & Day 22 - Extraordinary & & & \\
\hline & & & & Ordinary & & Extraordinary & Day 29 - Extraordinary & & & \\
\hline \multirow{4}{*}{ April } & \multirow{4}{*}{$\begin{array}{l}\text { Day } 13 \text { - } \\
\text { Ordinary }\end{array}$} & \multirow{4}{*}{$\begin{array}{l}\text { Day } 27 \text { - } \\
\text { Ordinary }\end{array}$} & \multirow{2}{*}{$\begin{array}{l}\text { Day 04 - } \\
\text { Ordinary }\end{array}$} & \multirow{3}{*}{$\begin{array}{l}\text { Day } 25 \text { - } \\
\text { Ordinary }\end{array}$} & \multirow{4}{*}{$\begin{array}{l}\text { Day } 15 \text { - } \\
\text { Ordinary }\end{array}$} & & Day 05 - Extraordinary & & & \\
\hline & & & & & & & Day 12 - Extraordinary & - & & \\
\hline & & & Day 26- & & & $\begin{array}{l}\text { Day } 20- \\
\text { Ordinary }\end{array}$ & Day 19 -Extraordinary & - & $\begin{array}{l}\text { Day 14- } \\
\text { Ordinary }\end{array}$ & - \\
\hline & & & Ordinary & $\begin{array}{l}\text { Ordinary } \\
\text { MSD* }\end{array}$ & & & Day 26 - Extraordinary & & & \\
\hline & & & & & & & Day 03 - Extraordinary & & & \\
\hline & & & & & & Day 18 - & Day 10 -Extraordinary & & & \\
\hline May & Day 24- & $\begin{array}{l}\text { Day } 30- \\
\text { Ordinary }\end{array}$ & $\begin{array}{l}\text { Day } 29 \text { - } \\
\text { Ordinary }\end{array}$ & Day $30-$ & $\begin{array}{l}\text { Day } 20- \\
\text { Ordinary }\end{array}$ & Ordinary & Day 17 -Extraordinary & - & - & - \\
\hline & & & & & & Day 31 - & Day 24 - Extraordinary & & & \\
\hline & & & & & & Extraordinary & Day 31 - Extraordinary & & & \\
\hline & & & & & & $\begin{array}{l}\text { Day } 15 \text { - } \\
\text { Ordinary }\end{array}$ & Doy 05 Evtmondingr & & & \\
\hline & Day 01 - & Day 28 - & Day 12 - & Day 30 - & Day 11 - & $\begin{array}{c}\text { Day } 09- \\
\text { Extraordinary }\end{array}$ & Day us - Extraordınary & & Day 26 - & Day 04 - \\
\hline June & Ordinary & Ordinary & Ordinary & Ordinary & Ordinary & $\begin{array}{c}\text { Day } 17- \\
\text { Extraordinary }\end{array}$ & Dov 28 Fytromdinon & - & Ordinary & Ordinary \\
\hline & & & & & & $\begin{array}{c}\text { Day } 21 \text { - } \\
\text { Extraordinary }\end{array}$ & Day 28 - Extraordınary & & & \\
\hline July & Day 29- & Day 31 - & Day 31 - & Day 31 - & Day 23 - & Day 20 - & Day 12 - Extraordinary & Dav 12 Oudinary & ${ }_{-}$ & - \\
\hline July & Ordinary & Ordinary & Ordinary & Ordinary & Ordinary & Ordinary & Day 21 - Extraordinary & Day 12 -Urdınary & - & - \\
\hline & & & & & & & Day 08 - Ordinary & & $\begin{array}{l}\text { Day } 21 \text { - } \\
\text { Ordinary }\end{array}$ & \\
\hline August & $\begin{array}{l}\text { Day } 03 \text { - } \\
\text { Ordinary }\end{array}$ & $\begin{array}{l}\text { Day } 28 \text { - } \\
\text { Ordinary }\end{array}$ & $\begin{array}{l}\text { Day } 21 \text { - } \\
\text { Ordinary }\end{array}$ & $\begin{array}{l}\text { Day } 28 \text { - } \\
\text { Ordinary }\end{array}$ & $\begin{array}{l}\text { Day 14- } \\
\text { Ordinary }\end{array}$ & $\begin{array}{l}\text { Day } 17 \text { - } \\
\text { Ordinary }\end{array}$ & Day 02 - Extraordinary & - & $\begin{array}{l}\text { Day } 22- \\
\text { Ordinary }\end{array}$ & $\begin{array}{l}\text { Day } 05 \text { - } \\
\text { Ordinary }\end{array}$ \\
\hline & & & & & & & Day 09-Extraordinary & & Day 23 - & \\
\hline & & & & & & & Day 30 - Extraordinary & & Ordinary & \\
\hline $\begin{array}{c}\text { Septembe } \\
\mathbf{r}\end{array}$ & $\begin{array}{l}\text { Day } 16 \text { - } \\
\text { Ordinary }\end{array}$ & $\begin{array}{l}\text { Day } 27 \text { - } \\
\text { Ordinary }\end{array}$ & - & $\begin{array}{l}\text { Day 26- } \\
\text { Ordinary }\end{array}$ & $\begin{array}{l}\text { Day } 16 \text { - } \\
\text { Ordinary }\end{array}$ & $\begin{array}{l}\text { Day } 06 \text { - } \\
\text { Ordinary }\end{array}$ & Day 20 - Extraordinary & Day 12 -Ordinary & - & - \\
\hline & & Day 11 - & & & & & & Day 10 - Ordinary & & \\
\hline & & Extraordi & Day 30 - & & & & & Day 31 - Ordinary & & \\
\hline October & $\begin{array}{l}\text { Day } 20 \text { - } \\
\text { Ordinary }\end{array}$ & nary & Ordinary & $\begin{array}{l}\text { Day } 30 \text { - } \\
\text { Ordinary }\end{array}$ & $\begin{array}{l}\text { Day } 2 /- \\
\text { Ordinary }\end{array}$ & $\begin{array}{l}\text { Day } 31 \text { - } \\
\text { Ordinary }\end{array}$ & - & Day 17 - Extraordinary & $\begin{array}{l}\text { Day } 22- \\
\text { Ordinary }\end{array}$ & $\begin{array}{l}\text { Day } 29- \\
\text { Ordinary }\end{array}$ \\
\hline & & Day $18-$ & MSD* & & & & & Day 24 - Extraordinary & & \\
\hline & & Ordinary & & & & & & Day 31 - Extraordinary & & \\
\hline & & & & & & & & Day 22 - Ordinary & & \\
\hline November & & & Day 28 - & Day 26 - & Day 27 - & & & Day 07 - Extraordinary & & \\
\hline November & Ordinary & Ordinary & Ordinary & Ordinary & Ordinary & - & - & Day 21 - Extraordinary & - & Ordinary \\
\hline & & & & & & & & Day 28 - Extraordinary & & \\
\hline December & Day 14 - & Day 19 - & Day 18 - & $\begin{array}{l}\text { Day 01 - } \\
\text { Ordinary } \\
\text { MSD* }\end{array}$ & Day 15 - & Day 02 - & - & Day 14-Ordinary & Day 18 - & Day 18 - \\
\hline & & Ordinary & Ordinary & Day 17 - & Ordinary & Ordinary & & Day 05 - Extraordinary & nary & Ordinary \\
\hline & & & & Ordinary & & & & Day 12 - Extraordinary & & \\
\hline
\end{tabular}

Note: * meetings whose content was not incorporated into the analysis, because they are ordinary meetings of the Municipal Tourism Fund (MSF), in which it was only the report of the expenses of the MSI.

Source: adapted from Juiz de Fora City Hall. Available from: https://www.pif.mg.gov.br/conselhos/turismo/atas_de_reunioes.php 
2021, SP (1): 89-109

https://doi.org/10.31822/jomat.2021-SP-1-89

\title{
INFO PAGE \\ The effect of position in the field in the development of public policies: Bourdieusian analysis of the Municipal Tourism Council of Juiz de Fora (2011-
}

\begin{abstract}
This work makes efforts for a theoretical-empirical analysis of public policies of tourism from the sociological theory of the social fields of Pierre Bourdieu. We start from the assumption that agents with a greater volume of capital would be able to interfere, more incisively, in the tourist field, particularly in their public policies, influencing more forcefully what can/should be and ends up being done, in a given context. Empirically, we took as study object the Municipal Council of Tourism of Juiz de Fora (COMTUR), heuristically as an approximation of the tourist field in general, and specifically the process of elaboration of public policies derived from it, in particular in terms of its results (decisions, actions and projects carried out), as a reasonably objective indicator of the operation of this field. A multi-methods approach was used, using different procedures (a) systematic and unsystematic observation of meetings, (b) description and recording of data in a diary note, (c) semi-structured interviews with key actors, (d) analysis of secondary data (minutes of COMTUR meetings from 2011 to 2020, as well as other data and historical records). The study is based on the composition of a cumulative database of observations, which has been constituted over the last decade, being specifically composed in the most part, regarding the study of COMTUR, by two studies, one conducted between 2015 and 2016, which recovered data from 2011 to 2015, and the other, conducted between 2019 and 2020, that compiled data from 2016 to 2020. We seek to identify the relationships between the different agents in the interactive dynamics of this social space, in terms of ideas, discourses and actions, as well as the positions of the agents, particularly the dominant ones, which stand out in relation to the others. We particularly highlight the relationships between proposed-proposals, approvedexecuted proposals, as well as between both and the volume of capital of the agents, especially the dominant ones, and finally the specific circumstances of each action (proposed and approved). The evidence points towards a direct relationship between the said volume of capital, the degree of participation in the meetings and the tendency to approve and eventual implementation of the proposals made by the agents with the highest volume of capital, who were at the center of the debate. It is concluded that the supposed democratic and "universal" openness in terms of the possibility of action is part of an ilusio of the field, which does not translate necessary, neither directly, in the real manifestation and participation in the field (COMTUR). It is said that the agents with the highest volume of capital tend to be those who, in a way, participate more in the actions and achievements of this sphere and, in this sense, are more likely to guide the local tourist context, as opposed to the actions of other agents in the field, who act as adjuvants. Therefore, any significant change in the field needs to include, in whole, or in part, those dominant agents.
\end{abstract}

Keywords: Bourdieu, Tourism, Tourist Councils

\begin{tabular}{l} 
Authors \\
\hline \begin{tabular}{c} 
Author contribution roles \\
\hline Full Name
\end{tabular} \\
$\begin{array}{c}\text { Marcela Costa Bifano de Conceptualization, Formal analysis, Writing - Original Draft, Writing - Review \& Editing, } \\
\text { Oliveira: }\end{array}$ \\
\hline $\begin{array}{c}\text { Fabiola Cristina Costa de Conceptualization, Formal analysis, Writing - Original Draft, Writing - Review \& Editing, } \\
\text { Carvalho: }\end{array}$ \\
\hline
\end{tabular}

Author statement: Author(s) declare(s) that All procedures performed in studies involving human participants were in accordance with the ethical standards of the institutional and/or national research committee and with the $1964 \mathrm{Helsinki}$ declaration and its later amendments or comparable ethical standards. Declaration of Conflicting Interests: The author(s) declared no potential conflicts of interest with respect to the research, authorship, and/or publication of this article

This paper does not required ethics committee report Justification: This research was conducted before January 1, 2020. For this reason, it is exempt from "ULAKBIM TRDizin" criterion. 